INÖNÜ ÜNIVERSITESI

HUKUK FAKÜLTESI DERGISI

\title{
ROMA HUKUKUNDA OTURMA HAKKI (HABITATIO)
}

\section{THE RIGHT OF HABITATION IN ROMAN LAW (HABITATIO)}

Sevgi KAYAK

DOI: https://doi.org/10.21492/inuhfd.554552

Dr. Ö̂jr. Üyesi, K̦tanbul Üniversitesi Hukuk Fakültesi, Roma Hukuku ABD (sevgiabhukuk@hotmail.com) ORCID: https://orcid.org/0000-0002-6147-6147

Makale Bilgi

Gönderilme: 16/04/2019

Kabul: 26/06/2019

\section{Anahtar Kelimeler}

Oturma Hakkē

Habitatio, Usus,

Ususfructus,

Servitutes.
Özet

Oturma hakkē, bakkasēêa ait bir evde oturma yetkisi veren sēê̄ēē ayni hak niteliĵ ini takēnaktadēe Roma hukukunda oturma hakkē Klasik Hukuk Döneminde baĵ̄ēnsēe bir irtifak olarak kabul edilmemiktir, bu hak usus hakkēkapsamēida ele alệ̂mēđēe. Bu nedenle Klasik Hukuk Döneminde, oturma hakkēile ilgili uyukmazlēklarda ususôa ilikkin hükümler kēesasen uygulanmēètē. Iustinianus Hukukunda ise, oturma hakkē ususâın kapsamēidan

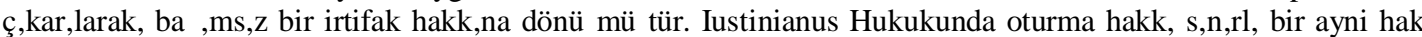
nitelîj indedir ve intuitus persona karakterine sahip bir in ius aliena (bakkasēê̄è malëüzerindeki hak)âlē. Oturma hakkēsậ lar arasēiklemlerle ya da ölüme bậ lētasarruflar yoluyla kurulur. Oturma hakkēkural olarak belli bir

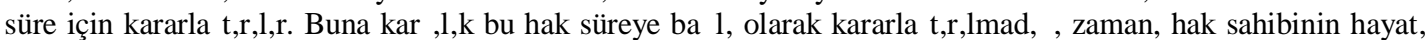
boyunca devam eder. Oturma hakkēsürenin sona ermesi, haktan feragat edilmesi veya mutatio rei (malēn esaslé dê̂ ikime uĵramasē gibi nedenlerle sona erer. Roma Hukukunda oturma hakkē ile ilgili kurallar modern hukuklara büyük ölçüde aynēkekilde geçmikir.

\section{Abstract}

The right of habitation is a limited right in the right to give habitation authority to someone else. The right of habitation in Roman law is not an independent easement in the Classical Law Period. This right is included under the right of usus. For this reason, in the Classical Law Period, the provisions of usus were applied comparatively. The right of habitation in Iustinianus Law has been removed from the scope of usus and turned into an independent easement right. The right of habitation in the Iustinianus Law is a limited right in kind and is an in ius re aliena with the character of intuitus persona. The right of habitation is established legal act or death-related savings. The right of habitation ends due to reasons such as the expiration of the period, the waiver of the right or the mutatio rei. The rules on the right of habitation in Roman Law are largely the same as those of modern law. 


\section{GENEL OLARAK}

Oturma hakkē genel anlamēêla, bakkasēea ait bir evde oturma yetkisi veren sēēēlēayni hakt $\overline{\mathbf{e}}^{1}$. Roma Hukuku

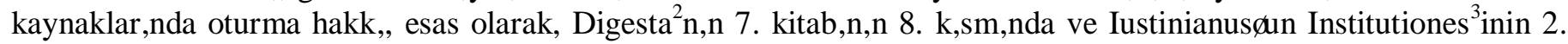

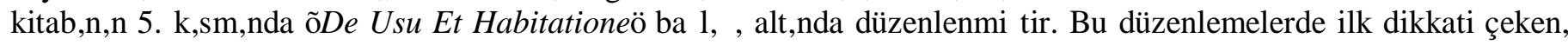
oturma hakkēè̄ baj ênsēe bir hak olarak kabul edilmeyikidir. Metinlerden anlakẻdề ềa göre, oturma hakkēuzunca bir zaman, tüm klasik çaĵ boyunca, Roma Hukukunda baj ênsēe bir hak olarak kabul edilmeyerek ñusus (kullanma

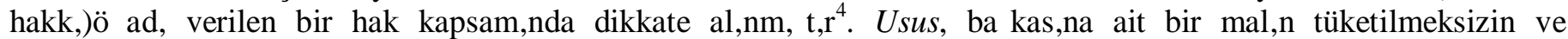

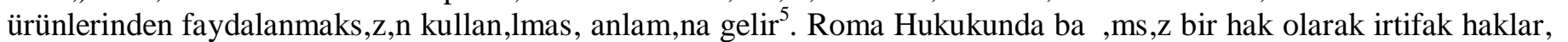
içinde sēêalanan usus, günümüzde bu nitelî̉ ini yitirerek sadece intifa hakkēkapsamềnda yer alan yetkilerden birine

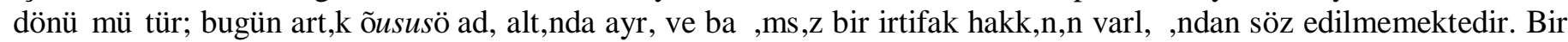

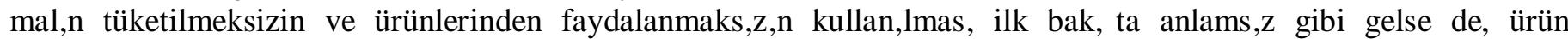

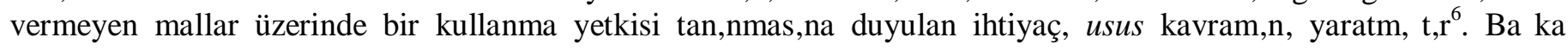
deyikle, bir kimseye tanēian kullanma yetkisi, ürün veren mallar üzerinde oldụ̂u zaman, genellikle o malēı ürünlerinden yararlanma yetkisini de içerecể inden, intifa hakkēkapsamēnda; tanēran yetki ürün vermeyen mallar üzerinde oldû̂ u zaman, usus kapsamēida görülmüKolacakt $\overline{\mathbf{e}}^{7}$.

Roma Hukukunda bir evin kullanēnēda Klasik Hukuk metinleri uyarēica usus kapsamēida görülmüktür. Bunun anlamē bir evde oturmak demek olan habitatioônun, Klasik Devir boyunca usus kapsamēēdaki kullanēn kekillerinden biri gibi düKinülerek bậ̂̄nsēe bir irtifak mahiyetinde deĵil, ususâın bir içerî̄ indeki bir yetki gibi dej erlendirilmesidir ${ }^{8}$. Bizi bu sonuca götüren nedenler arasēèda, özellikle D. 7. 8. 2. 1 metninin, ñDomus usus relictus est aut marito, aut mulierié ( bir evin kullanēnēkadēn eKe ya da erkek eKe vasiyet ediliré )ò ile baklayan cümlesi gelmektedir. Zira bu cümlede bir ev üzerindeki kullanēn hakkēidan, ñhabitatioò olarak deĵ il, ñususò olarak bahsedilmektedir. Oturma hakkēile kullanma hakkềiề aynēkey olup olmadề ềēirdeleyen D. 7. 8.10 pr. metni ise, bu konuda daha aç bir kanē sunar:

D. 7. 8. 10 pr. Ulpianus lib. 17. ad Sabinum

Si habitatio legetur, an perinde sit atque si usus, quaeritur? Et effectu quidem idem pene esse legatum usus et habitationis, et Papinianus consensit libro octavo-decimo Quaestionum. Denique donare non poterit: sed eas personas recipiet quas et usuarius. Ad heredem tamen nec ipsa transit: nec, non utendo amittitur, nec capitis diminutione.

D. 7. 8. 10 pr. Ulpianus Sabinus hakkēida 17. kitabēidan

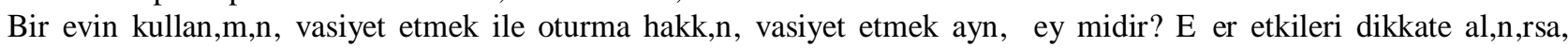
Papinianus, habitatio ve usus vasiyetinin hemen hemen aynēoldû̂ unu ñSorularò hakkēidaki 18. kitabēèda teyit ediyor.

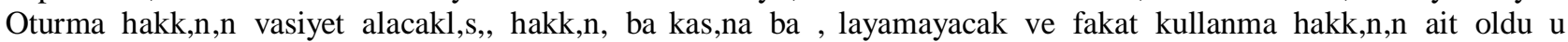
Kahēlara devri kabul edilecektir. Oturma hakkēmirasçēa geçmez, kullanmamakla veya capitis deminutioôja ụ̂ ramakla

${ }^{1}$ KARADENæ̧ ÇELEBł̣CAN, Özcan: Roma Ekya Hukuku (EKya), Yeni Medeni Kanunô Uyarlanmēe 5. Basēn, Turhan Kitabevi, Ankara 2015, S. 281.

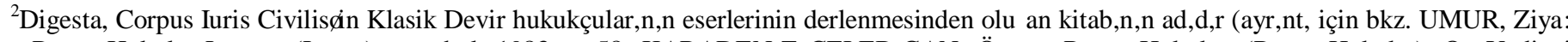
Roma Hukuku Lügatē (Lügat), K̦tanbul, 1983, s. 58; KARADENKᄍ ÇELEBKCAN, Özcan: Roma Hukuku, (Roma Hukuku), On Yedinci Basēn, 2014, Turhan Kitabevi, Ankara 2014, s. 51-52; UMUR, Ziya: Roma Hukuku, (Roma Hukuku), Filiz Kitabevi, K̦tanbul 1984, s. 261 vd.; TAHא̦OĴ LU, Bülent/ERDOĴ MUk, Belgin: Roma Hukuku, Onuncu Basēn, Der Yayēılarē Kstanbul 2014, s. 90-92).

${ }^{3}$ Institutiones, Corpus Iuris Civilisân ôj rencilere hukuk kurumlarēēē ö̂̀ retebilmek amacējla hazēelanmēe dört temel kitabēendan biridir (KARADENĶ ÇELEBß̧CAN, Roma Hukuku, s. 50-51; GÜNEk̦ CEYLAN, Seldaĵ, ñRoma Hukukunda Klasik Hukuk Dönemiò, Prof. Dr.

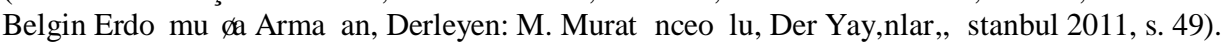

${ }^{4}$ ACCARIAS, C.: Précis De Droit Romain, Tome I, 4. éd., Paris 1891, s. 720.

${ }^{5}$ MONIER, Raymond: Manuel Elémentaire De Droit Romain, Tome I, 6. édition, Paris 1947, s. 438.

${ }^{6}$ Roma hukukunda ñususò sözcü̂̂ ünün iki anlamēdaha vardēe: Bunlardan ilki ve en eskisi, ñbir hakimiyet hakkēea sahip olmakò manasēnda ñzilyetlikòir. Zira Eski Hukuk devrinde zilyetlik, ñususò tabiri ile ifade edilmikir (KARADENĶ ÇELEBKCAN, EKya, s. 110-112; KARAGÖZ, Havva: Traditio (Teslim)ônun Tarihsel Gelikimi Ve Constitutum Possessorium (Zilyetlik Anlakmasề, Der Yayềnlarē kștanbul 2001, s. 29. Kরinci kullanēmēnda usus, kadēı eK üzerinde erkek ekin sahip oldụ̂ u bir tür hakimiyet demek olan manusânn zamanakēmēyoluyla

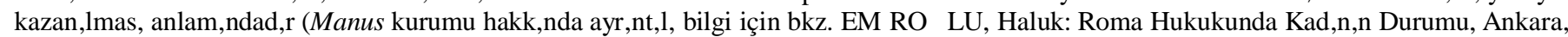
2003, s. 40; TAHAN ORHAN, Duygu: Roma Hukukunda Manus Kurumu, On K̦i Levha Yayēcēę, K̦tanbul 2018, s. 35-40). Usus kavramēēêt üç farklēanlama sahip olmasēe doĵ al olarak bize ku soruyu sordurmaktadēê: Usus sözcï̂̀ ü ile ifade edilen bu kurumlar arasēenda bir baĵ lantēvar mềēê, yoksa birbirinden farklēbu kurumlarēe aynēsözcük ile ifade edilmesi bir tesadüf müdür? Kabul etmek gerekir ki usus sözcuî̉ ünün anlamē buna karar vermek için oldukça mụ̂ laktēe. K̦k zamanlarda ususôın, bir mala zilyet olmayē ifade etmekten bakka, zilyetlikten çok daha genikbir anlamē her türlü fiili hakimiyeti ifade ettîj i fikri ileri sürülmükür, (bu yönde bkz. KARAGÖZ, s. 30). O halde ususồn ilk anlamē̄ēè, bir keye fiilen hakim olmak keklinde belirdî̉ ini söyleyebiliriz. Bu bakēndan fikrimize göre bu anlamdaki usus, her türlü

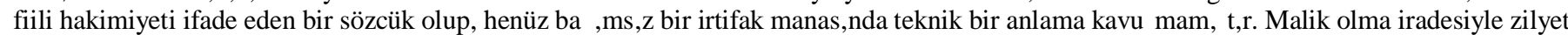
olmanē zaman içinde possessio sözcüj ü ile ifade edilmeye bakanmasēlla bu nevi hakimiyet halleri ususân kapsamēndan çēkarken, malik olma iradesi bulunmaksēēè sahip olunan hakimiyet halleri için de detentio sözcüj ü yerlekmikir. (ERDOĵ MUk, Belgin: Roma Ekya Hukuku, Der Yayēllarē Kștanbul, 2000, s. 18-20). Kadē üzerindeki hakimiyetin zamanakēnēile kazanēmasēanlamēèdaki usus ise, manusâu evlilik birliklerinin giderek azalmasē ve nihayet ortadan kalkmasēlla gözden kaybolmukur (TAHAN ORHAN, s. 64 vd.) Böylece usus, mal üzerindeki bir fiili hakimiyeti ifade etmekten çok, mal üzerindeki kullanēm yetkisini ifade eden bir sözcükten ibaret kalmēđēe.

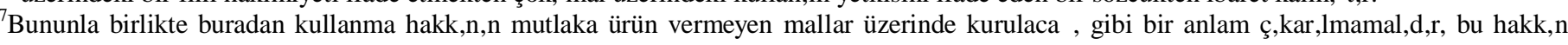
ürün veren mallar üzerinde tesisi de mümkündür. Malik, malēüzerindeki kullanma hakkēēẹ onun ürünlerinden yararlanma hakkēêēayrētutarak tanējorsa, kurulan ilikki usus olarak nitelendirilecektir. (PETIT, Eugène: Traité Elémantaire de Droit Romain, 9. éd., Paris 1925, s. 252).

${ }^{8}$ ACCARIAS, s. 353.

Roma Hukukunda Oturma Hakkē(Habēatēe) 
ile hak son bulmaz.

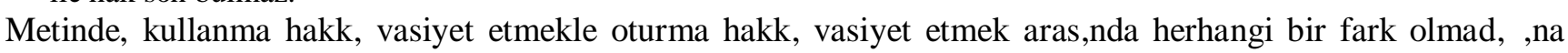
dikkat çekilmesi, oturma hakkēēē Klasik Dönem boyunca usus kapsamēida ele alēểê̄ēe bir göstergesidir. Ancak,

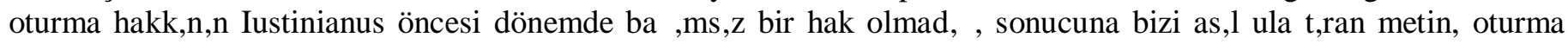
hakkēēên kendine özgü baj ềnsēe bir hak haline getirildî̉ ini belirten I. Inst., 2. 5. 5âir:

Sed si cui habitatio legata sive aliquo modo constituta sit, neque usus videtur neque ususfructus, sed quasi proprium aliquod ius. é

Ej er belirli mal vasiyeti veya bakka bir vasēayla bir oturma hakkētesis edilmikse, burada ne kullanma ne de intifa hakkēolup kendine özgü bir hak vard $\bar{e}^{9}$. é

Metinde, oturma hakkēê̄ ister saĵ lar arasēister ölüme baĵ lēiKlemlerle tesis edilmiKolsun, kullanma ya da intifa hakkēile izah edilemeyecek kadar kendine özgü ve baĵ̄̄nsēe bir hak olduj una vurgu yapeెmaktadēe Bu da Eski Hukuk Döneminden Iustinianus Hukukuna gelinceye kadar, oturma hakkēêē baj ềnsēe bir hak gibi düKinülmedî̉ ini, bu düKuncenin ilk kez Iustinianus Hukukunda gündeme getirildî̂ ini göstermektedir. Oturma hakkēēe Iustinianus öncesi dönemde baj ềns $\bar{e}$ bir hak olarak dikkate alēmmayēēēêen nedenini, oturma yetkisinin sadece maddi bir fiil olarak görülmesine baj lamak gerekir. Gerçekten, bir evde oturmak, malē kullanēen kekillerinden yalnēea biridir ${ }^{10}$. Bu bakēndan bir ev üzerinde tanēenan oturma yetkisi, Roma Klasik Dönemi boyunca baj̄ēnsēe bir hak olarak deĵ il, usus veya ususfructus kapsamēēda ele alēian bir tür kullanma yetkisi olarak görülmü Kür. Eĵ er bir evde oturma yetkisi, onun ürünlerinden yararlanma yetkisi de tan̄̄

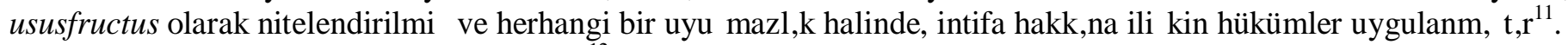

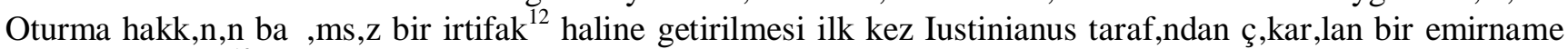

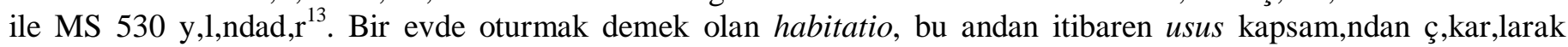
teknik bir anlama kavuKurulmuKur. Habitatioônun kurulmasē korunmasē ve sona ermesi hakkēê intifa hakkēê ilikkin hükümlerin kēeasen uygulanmasē da Iustinianus hukukunun bir bakka kabulüdür ${ }^{14}$. Iustinianus hukukunun habitatioôja ilikkin bu düzenleme anlayēđēmodern hukuka da takēmmē ve oturma hakkēmilli kanunlarda bu bakē巛

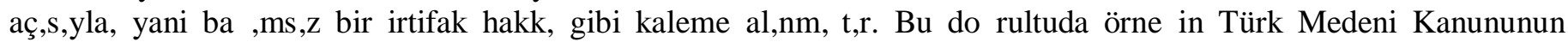
oturma hakkēia ayrēan 823-825. maddeleri oturma hakkēiēbaj ềnsēe bir irtifak hakkēolarak düzenlenmektedir.

Oturma hakkēTürk Hukukunda Türk Medeni Kanununun 823-825. maddeleri arasēida olmak üzere üç madde halinde düzenlenmikir. TMK m. 823âe oturma hakkēidan izleyen Kekilde bahsedilmektedir:

Oturma hakkē bir binadan veya onun bir bölümünden konut olarak yararlanma yetkisi verir. Oturma hakkē bakkasēia devredilemez ve mirasçeెara geçmez.

Kanunda aksine hüküm bulunmadēkça intifa hakkēia ilikkin hükümler oturma hakkēia da uygulanē.

Buna göre Türk Hukukunda oturma hakkēêdan anlakẻan, bir binadan veya onun bir bölümünden yararlanma

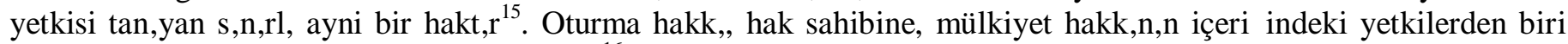
olan usus (kullanma) yetkisini sâj ladệ ēiçin ${ }^{16}$, mülkiyet hakkēēē bir parçasēolarak ayni nitelikte bir haktēe Oturma

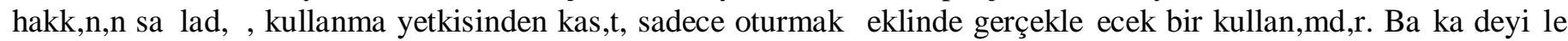
oturma hakkēêê saj ladê ē yetki, bir binanē tamamēēēya da bir bölümünü konut olarak kullanmaktan ibaret bir

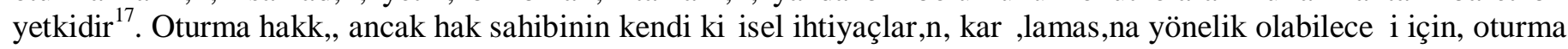
hakkēēē bakkasēêna devredilmesi de mümkün dejildir. Oturma hakkē devrinin ya da miras yoluyla intikalinin söz

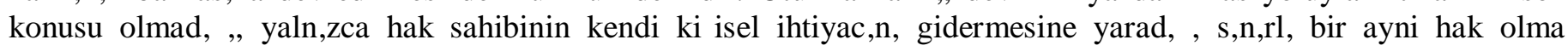

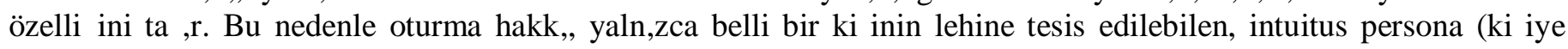

${ }^{9}$ Çalērmamēeda kullandêēenē Iustinianus Institutiones metinlerinin çevirisinde, IUSTKNKANUS INSTKUTTKNES, Türkçe metin: Ziya Umur, K̦tanbul, Kstanbul Üniversitesi Yayēilarē 1968 adlēeserden yararlanẻmēè $\bar{e}$.

${ }^{10}$ ÁCCARIÁS, s. 720-721.

${ }^{11}$ ACCARIAS, s. 721. Oturma hakkēēè baĵ ēnsē bir hak olarak görülmeyikinin en önemli neticelerinden biri de hiç Kiphesiz, bu hakkē ekler

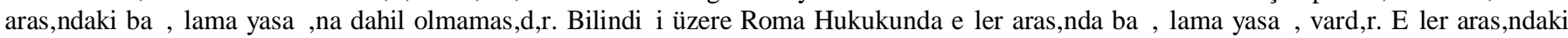
ilikkinin maddi deĵ erlerle ölçülmesini öteden beri hok kark®̉amayan Roma toplumu, bu yasẩ ëönce örf ve adetlerde benimsemik sonra da bu

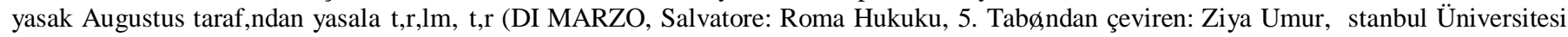

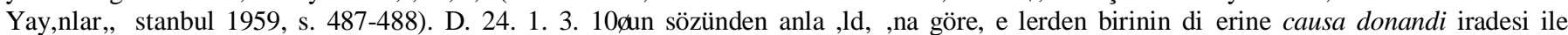
yaptê ēkazandēêmalarē hiçbiri hukuken geçerli olmayacaktēe (DUMONT, François Les Donations Entre Epoux En Droit Romain, Paris, 1928,

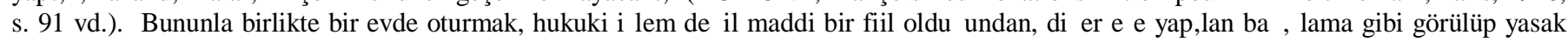

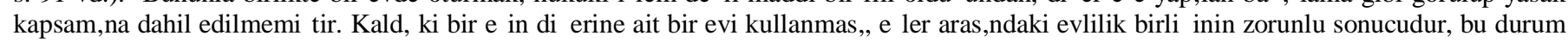
taraflar arasē̄da bir bậ ējama sözlekmesinin mevcut bulundụ̂ u anlamēèda yorumlanamaz.

${ }^{12}$ I., Inst., 2. 5. 5.

${ }^{13}$ C. 3. 33. 13. Ayrēa bkz. KARADENĶ ÇELEBKCAN, EKya, s. 282.

${ }^{14}$ KARADENKৃ ÇELEBKCAN, Ekya, s. 282; Umur, Ziya: Roma Hukuku, Ekya Hukuku (Ayni Haklar), (Ekya), Filiz Kitabevi, K̦tanbul 1985, s. 152.

${ }^{15}$ Sא̦MMEN, Lale A.: EKya Hukuku, 4. Baskēē Ankara, Yetkin Hukuk Yayēêlarēe, 2016, s. 544; ESENER, Turhan /

GÜVEN, Kudret: EKya Hukuku, Genikletilmik6. Baskēe Ankara, Yetkin Yayēilarē 2015, s. 422 vd.

${ }^{16}$ AKINTÜRK, Turgut: EKya Hukuku, K̦tanbul, Beta, 2009, s. 696.

${ }^{17}$ AKINTÜRK, s. 696. Kanun metninde açđ̄ça ñkonutò olarak dedî̉ i için, konut dē đēenda bakka bir amaçla, mesela ticarethane ya da ikyeri olarak kullanēn bu kapsamda görülemez (AKINTÜRK, s. 696; KÖPRÜLÜ, Bülent /KANETĶ Selim: Sēê̄elē Ayni Haklar, Geniketilmik ve YenilenmiK2. Basē Kstanbul, 1982-1983, s. 152-153.

Sevgi KAYAK 


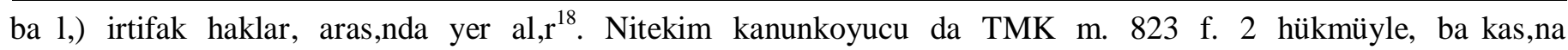
devredilemeyeceĵ ini ve miras yoluyla geçmeyecej ini belirterek hakkēi kikiye baĵ lēę nitelị̂ ini ayrēa teyit etmikir.

\section{OTURMA HAKKI KAVRAMI}

\section{A. Kavramēin Anlamēve Hukuki Niteliĵ i}

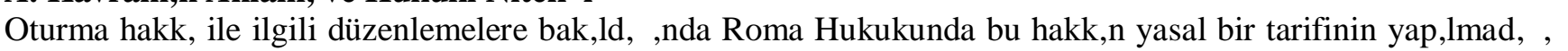
hemen fark edilir. Bununla birlikte, bir evin kullanēmasēeldan bahseden Digesta metinleri ile oturma hakkēēe

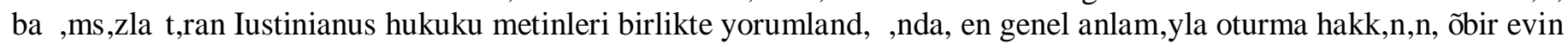

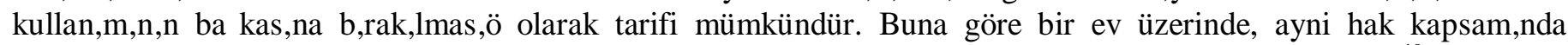

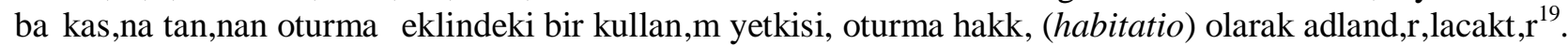

Oturma hakkē hak sahibine bir konut sậ lama düKincesinden doĵ mukur ${ }^{20}$ ve mülkiyet hakkēê̄i içerî̉ indeki yetkilerden birini, kullanma yetkisini saj ladê ēiçin de bir ayni haktēe. Bunun gerê̂ i olarak herkes tarafēedan ihlal

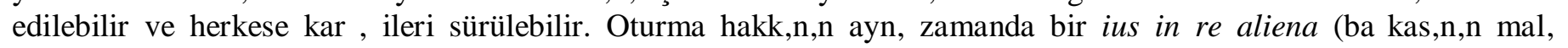
üzerindeki hak) olduj unu da ilave etmelidir. Ius in re aliena, malikin malëüzerinde sahip oldû̂ u yetkilerden birini ya

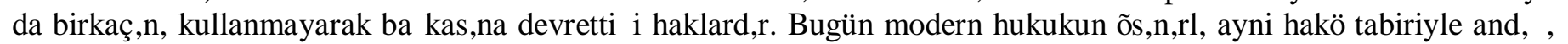
in ius re aliena, maliki bu yetkilerin bakkasētarafēendan kullanēmasēe katlanma borcu altēnda bēektê ēiçin mülkiyet hakkēēēsēiēlayēēnitelikte haklarde $\bar{e}^{21}$.

Sēê̄è̄eir ayni hak nitelî̀ inde olan oturma hakkēaynēzamanda kikiye baĵlēbir irtifak hakkēolarak kabul edilmikir $^{22}$. Bunu özellikle D. 7. 8. 8 pr. metninden anlējoruz:

D. 7. 8.8 pr. Ulpianus Lib. 17 ad Sabinum

Sed neque locabunt seorsum, neque concedent habitationem sine se, nec vendent usum.

D. 7. 8.8 pr. Ulpianus Sabinus hakkēndaki 17. kitabēidan

Kullanēn hakkēsahipleri, kendileri orada oturmaksēề̄ ne oturma hakkētanējabilirler, ne onu kiralayabilirler, ne de kullanma hakkēēēsatabilirler.

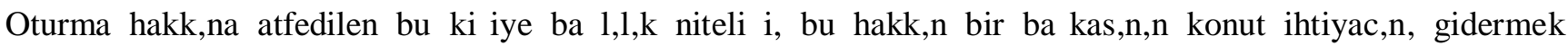

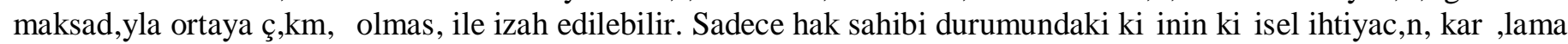
düKincesi, bu hakkēe hak sahibinden bakkasēe devrine ya da miras yoluyla intikaline izin vermemikir. Oturma

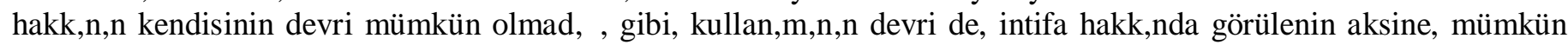

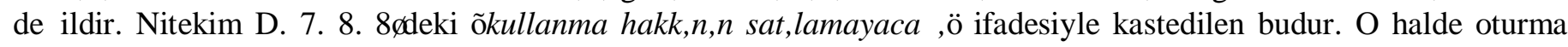

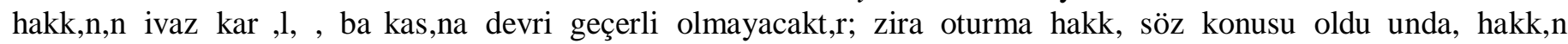

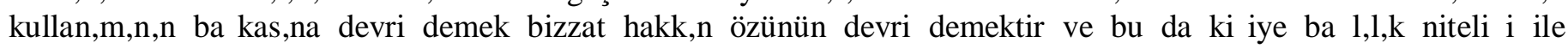
baĵ dakmaz. Oturma hakkē sadece hak sahibinin oturmasēēëöngördüĵ̉ ünden, bir evde kendisi oturmak yerine bakkasēēē

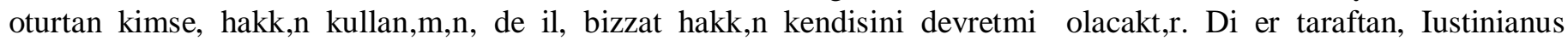

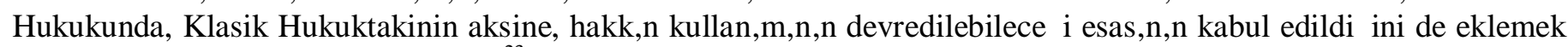
gerekir. I. Inst., 2. 5. 5ôn son cümlesi ${ }^{23}$ bundan bahsetmektedir:

é Quam habitationem habentibus propter rerum utilitatem secundum Marcelli Sententiam nostra decisione promulgata permisimus non solum in ea dej ere, sed etiam aliis locare.

é Oturma hakkē sahiplerine, Marcellusâın fikrine ve fayda prensibine uygun bir kararēnēe göre, orada ikamet etmekten bakka, bakka kimselere de kiralayabilmek izni verilmikir.

Bu durumda Klasik Hukukta tanē̄an oturma hakkē ya usus ya da ususfructus kapsamēêdaki bir yetkiden ibaret olacakt $\bar{\oplus}$. Bir evde oturma yetkisi, bu evin hukuki ürünlerinden, yani kira gelirinden faydalanmaksēềi salt oturmaktan

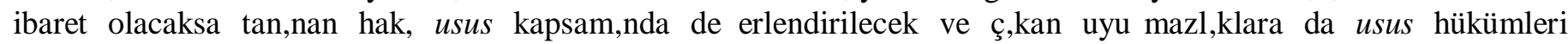
uygulanacaktēe. E $\hat{\jmath}$ er tanēian yetki, evin kira gelirinden yararlanma yetkisini de içeriyorsa, ususfructus niteliĵ i aj $\bar{\Theta}$

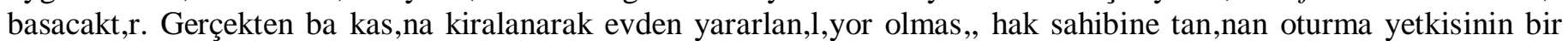

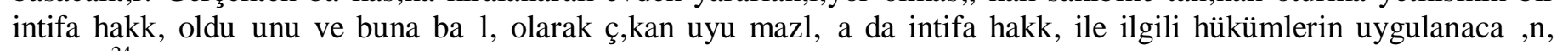
gösterir $^{24}$.

\section{B. Oturma Hakkēēè Benzer Hukuki Kurumlardan Farkē}

1. Oturma Hakkēł̣e Kullanma HakkēArasēidaki Fark

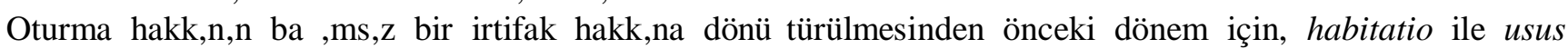

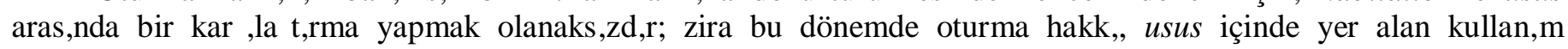

\footnotetext{
${ }^{18}$ OĴ UZMAN, M. Kemal/ SELł̧̧̧̧̋̈Zer: Ekya Hukuku, 9. Basē K̦tanbul, Filiz Kitabevi, 2002, s. 634.

${ }^{19}$ CUQ, Edouard: Manuel Des Institutionis Juridiques Des Romains, 2. éd., Paris, 1928, S. 342; LEPOINTE, M: Cours De Droit Romain, Paris,

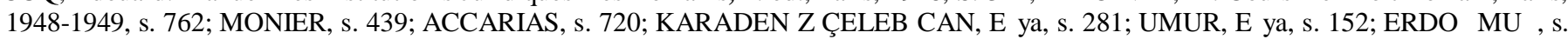
115.

${ }^{20}$ LEPOINTE, s. 762.

${ }^{21}$ In ius re aliena hakkēida bkz. UMUR, Ekya, s. $133 \mathrm{vd}$.

${ }^{22}$ SEIDL, Erwin: Römisches Privatrecht, 1963, § 14 N. 241

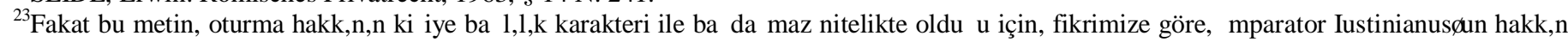
dôj asēêna ters düken bir tasarrufu olarak yorumlanmalēēē.

${ }^{24}$ ORTOLAN, M.: Explication Historiques Des Instituts De LôEmpéreur Justinien, Tome II, 8. éd., Paris, 1870, s. 353.

Roma Hukukunda Oturma Hakkēe(Habēatēe) 
biçimlerinden yalnēca biridir. Bir evde oturmak keklinde tanēan yetki, baĵ ênsēe bir habitatioôja deĵ il, evi konut olarak kullanmak konulu bir usus hakkē dê̂ il, usus olacâ̄ ē ve taraflar arasēeldaki uyukmazlēklara da doĵ rudan ususô ilikkin hükümlerin tatbik edileceĵ $\mathrm{i}$

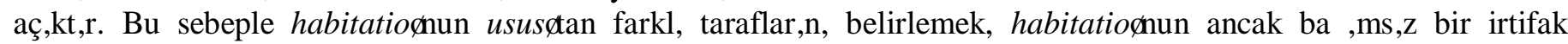
hakkēēēalmasēêndan sonraki dönem için anlamlēolacaktēe. Iustinianus Hukukunda baje ênsēe bir irtifak halini alan habitatio, bu andan itibaren hukuki bir kuruma dönükmüћür. Böylece, daha önce bünyesinde yer aldê ēususâan da bazētemel farklarla ayrēmètsè

Usus, daha önce de söyledî̂ imiz üzere bakkasē̄a ait malē onun özüne dokunmaksēēề ve ürünlerini toplamaksēề kullanmak yetkisi demek olup ${ }^{25}$ burada hak sahibine verilen yetki, malēyalnēea kullanmaktan ibaret bir ius utendiôlir. Buna açça temas eden metin D. 7. 8. 2âlir:

D. 7. 8. 2 Ulpianus Lib. 17 ad Sabinum

Cui usus relictus est, uti potest, frui non potesté

D. 7. 8. 2 Ulpianus Sabinus hakkē̄idaki 17. Kitabēidan

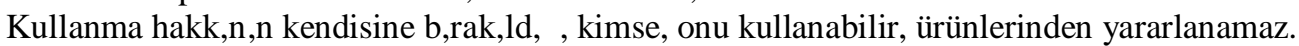

Usus, bir malē ürünlerini toplamak hariç, mal üzerinde her türlü kullanēn yetkisini içerecek tarzda tesis

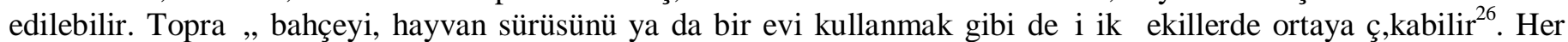

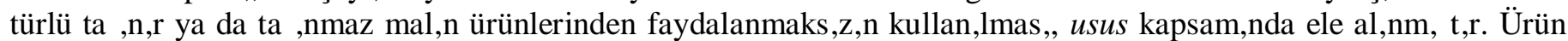

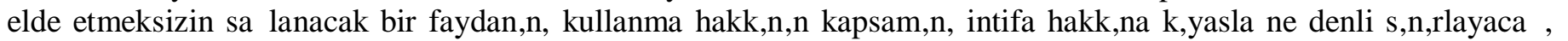

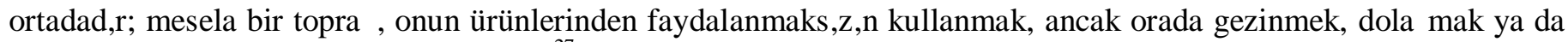
dinlenmek gibi fillerle mümkün olacakt $\bar{\Theta}^{27}$. Gerçekten de bu mallarēe onlarēen ürünlerinden yararlanmaks $\bar{e} \bar{e} \mathbf{~ k u l l a n m a ~}$

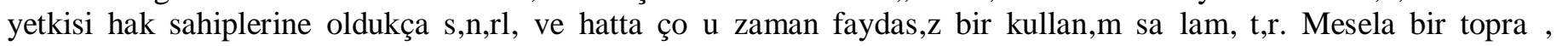
kullanmak hakkēo toprak üzerinde gezinmek, dolakmak ya da orada dinlenmek gibi fillerle sēêêlēolmukur. Bir kölenin ya da hayvanē $\bar{\oplus}$ üzerinde usus elde eden kimse de benzer durumdadēe ; köle ya da hayvanēçiftlik iklerinde çalēđēeabilir ya da ev hizmetlerinde onlardan yararlanabilir ancak bu mallarē ürünlerini kesinlikle elde edemez. Yani köleyi bakkasēe kiralayarak bir kira geliri edemeyecê̂ i gibi hayvanlarēı sütü, yünü, yavrularēgibi doĵ al ürünlerinden de yararlanamaz ${ }^{28}$, bu ürünler malikte kalmaya devam eder $^{29}$.

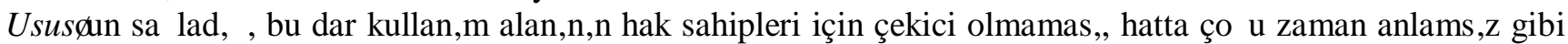
görünmesi, daha Klasik Dönemden itibaren, ususần içerî̉ indeki yetkileri genikletme ê ilimini baKlatmēđe $\bar{e}^{30}$.

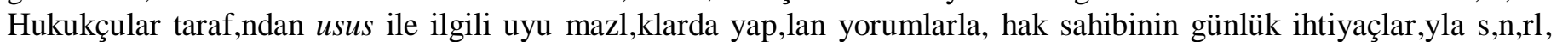
olmak kaydēella malēi bazēürünlerinin elde etmesine izin verilmikir. Mesela bir koyun sürüsü üzerindeki ususân, hak

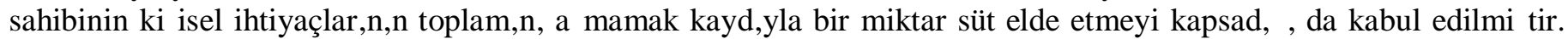
Yine bir bahçe üzerindeki ususâa da, bahçeden kikisel gereksinimleri karkł̉ayacak kadar sebze meyve toplanmasēia cevaz verilmikirir ${ }^{31}$.

Aynēsonuç, vasiyetname ile tesis edilen usus hakkēiçin de geçerlidir. Vasiyet edenin iradesinin hak sahibine

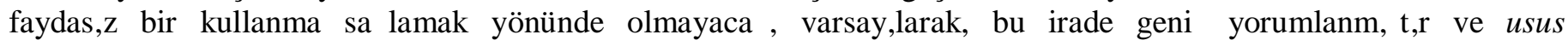

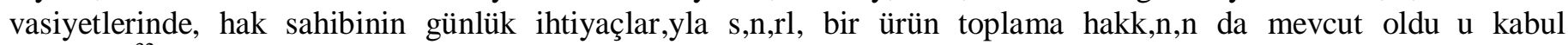
edilmikir ${ }^{32}$. Ususô ilikkin bu genikletici yorumlar usus kurumunun giderek intifa hakkē̄a yaklakmasệa neden olmukur. Ancak ilginç olan, bu yakēllakmaya raĵ men ususâın intifa hakkēbünyesinde eriyip gözden kaybolmayarak,

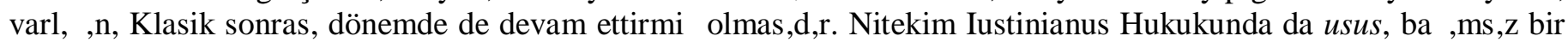
irtifak hakkēolarak korunmaya devam etmektedir. Kullanma hakkēề̊ Iustinianus hukukundaki çizgileri I. Inst. 2. 5. 1ôle Ku kekilde ifade edilmektedir:

Minus autem scilicet iuris in usu est quam in usufructu. Namque is, qui fundi nudum usum habet, nihil ulterius habere intellegitur, quam ut oleribus, pomis, floribus, feno, stramentis, lignis ad usum cottidianum utatur: in eoque fundo hactenus ei morari licet, ut neque domino fundi molestus sit neque his, per quos opera rustica fiunt, impedimento sit: vendere aut locare aut gratis concedere potest, cum is, qui usufructum habet, potest haec omnia facere.

Ususâlaki hak sahasēintifadakinden azdēe. Gerçekten bir kimse bir arazi üzerinde sēef kullanma hakkēè̄haiz olunca, sadece oradan, günlük ihtiyaçlarēđda kullanmak üzere sebze, meyve, çilek, yulaf, saman, odun alabilir; o arazide ikamet etmesi de caizdir, yeter ki ne arazinin malikine rahatsēelë versin, ne de orada yapēan ziraat ikerine mani olsun: esasen, haiz oldụ̂ u hakkēbakkalarēe ne kiralayabilir, ne satabilir ne de parasêe olarak terk edebilir; halbuki intifa hakkēèēhaiz olan, bunlar $\bar{\oplus}$ hepsini yapabilir.

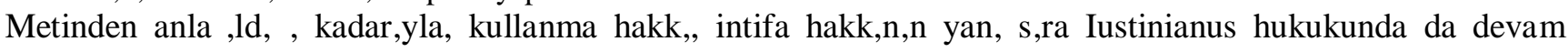

\footnotetext{
${ }^{25}$ MONIER, s. 315; CUQ, s. 340; DI MARZO s. 302; SCHMIDLIN, Bruno/ AUGUSTO CANNATA, Carlo: Droit Privé Romain, II, Lausanne,

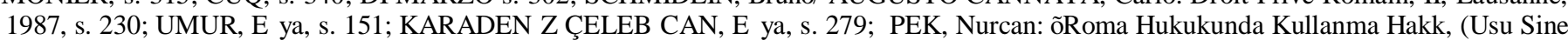
Fructus), Maltepe Üniversitesi Hukuk Fakültesi Dergisi, 2009/1, s. 219.

${ }^{26}$ SCHMIDLIN /CANNATA, s. 230.

${ }^{27} \mathrm{Bu}$ gerekçeyle usus, geleneksel yoruma göre, sēê̄elēbir intifa hakkēeldan bakkasēdeĵ ildir (PETIT, s. 252).

${ }^{28}$ Bir koyun sürüsü üzerinde tanēinan usus da, hak sahibine, sürüyü otlatmak veya gübre elde etmek dē̄ēnda hiçbir yarar saĵ lamaz (ORTOLAN, s. 349; CUQ, s. 340).

${ }^{29}$ PETIT, s. 252.

${ }^{30}$ KARADENKZ ÇELEBKCAN, EKya, s. 280; DI MARZO, s. 302.

${ }^{31}$ CUQ, s. 341; PETIT, s. 252; KARADENKৃ, ÇELEBKCAN, EKya, s. 280; DI MARZO, s. 302.

${ }^{32}$ PETIT, s. 252.

Sevgi KAYAK 
etmektedir. Hak sahibine, günlük tüketim miktarēile sēê̄lē olmak kaydēela usus konusu malēe ürünlerinden

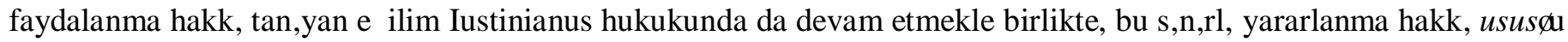

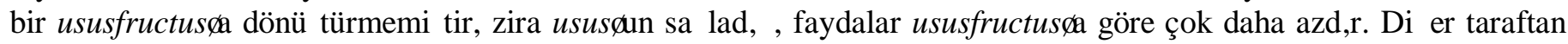
ususâın, modern hukuklara geçmedị̂ ini, Roma hukukuna özgü bir kurum olarak kaldê ệ̂̄da ilave etmek gerekir.

Usus, gerek Klasik gerek Iustinianus Hukukunda kikiye baĵ lēbir irtifak hakkēelēe bakkalarēia devri ya da miras

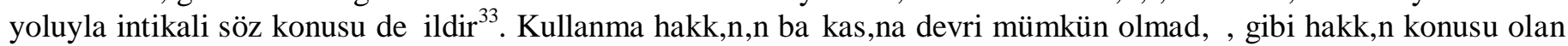
malệ bakkasēna kiralanmasēda kabul edilmemikir. Böyle olmasēda dộ aldēe zira üzerinde kullanma hakkēbulunan

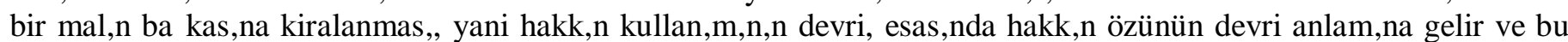

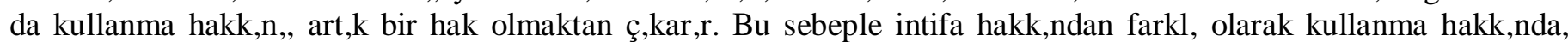
hakkē̄ kullanēnēêề devri gibi bir imkan söz konusu deĵ ildir ${ }^{34}$.

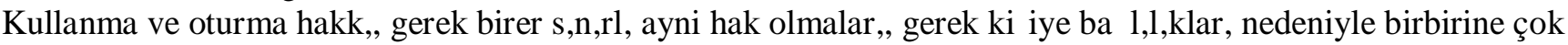

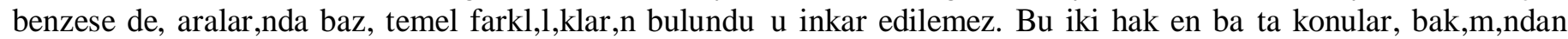

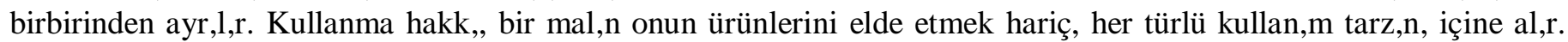

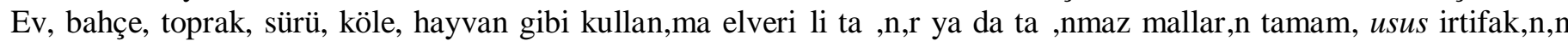
konusunu olukurabilir. Habitatio ise, yalnēca bir bina ya da ev üzerinde söz konusu olabilecek bir yetki olup, evin ya

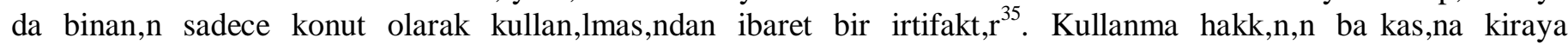

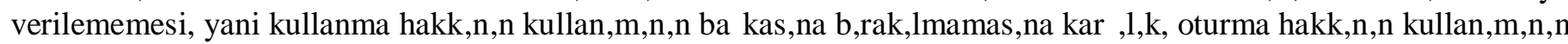
Iustinianus tarafēèdan bakkasēna devredilebilir nitelikte kabulü, her iki hak arasēêdaki dîj er bir farktēe. Iustinianus, oturma hakkēê̄i konusu olan evin kiraya verilebilecê̂ ini kabul ederek, oturma hakkēile kullanma hakkēarasēida önemli bir farklëe yaratmèđe $\bar{e}^{36}$.

Usus ile habitatio arasēèdaki bir bakka fark da, ususâa hakkē̄ kullanēmamasēya da hak sahibinin capitis

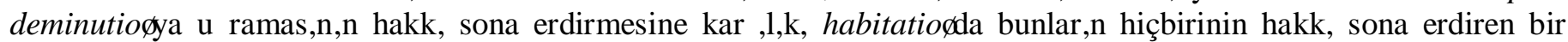
sebep olmamasềlēe. Bakka anlatēnla oturma hakkēsahibi, hakkēèēkullanmamakla ya da hak ehliyetini kaybetmekle

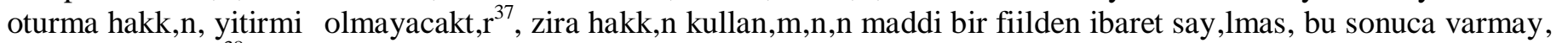
gerektirmektedir ${ }^{38}$.

\section{Oturma HakkēKe Kutifa HakkēArasēidaki Fark}

Roma hukukunda ususfructus sözcüjü ile ifade edilen intifa hakkē bakkasēēē malēüzerinde, malēı özünü koruyarak tanēian kullanma ve malēe ürünlerden faydalanma yetkisidir ${ }^{39}$. Malē̄ üzerindeki her türlü kullanēn yetkisini sậ ladẹ ēiçin intifa hakkē o mala ait ürünlerden yararlanma yetkisini de içerir. Ķntifa hakkēbir ius in re aliena olup kikiye baĵ lēirtifak hakkēlēe. Hak konusu olabilecek eKya bakēnēindan dej erlendirildî̉ inde, intifa hakkēile

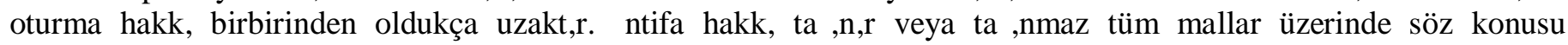
olabilirken, oturma hakkēyalnēeca ta Kēmmazlar üzerinde söz konusu olabilir. Ķntifa hakkē hak konusu malēe dojal ya da hukuki ürünlerinden faydalanma hakkēverdî̂ i halde; oturma hakkē bir evde ya da binada sadece oturma keklinde kullaneెacak bir yetki verir, evin hukuki ürünlerinden faydalanma hakkēsâ̂ lamaz. Diĵ er taraftan, bahsettî̉ imiz bu

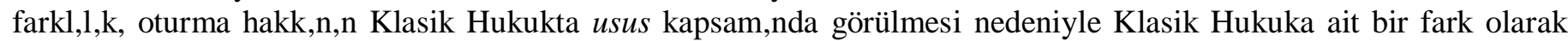

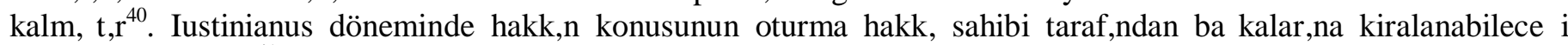
kabul edildî̄ $\mathrm{i}$ için ${ }^{41}$, her ne kadar bu kira gelirinden ilgili metinde ürün olarak bahsedilmese de, evin ürünlerinden yararlanmak, yani evi kiraya vererek kullanmak da mümkündür.

Malik tarafēèdan tanēnan bir evde oturma yetkisinin intifa mēyoksa oturma hakkēmēoldụ̂ u konusunda Kiphe

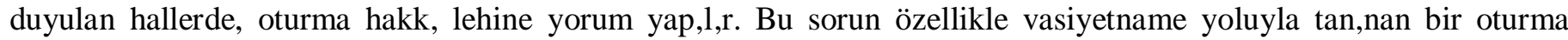
yetkisi bakēnē̄dan gündeme gelmikir. Malikin, bir ev üzerinde hem oturma hem de ondan yararlanma anlamēea gelecek ifadelerle belirli bir mal vasiyeti kaleme almasēhalinde, hakkē niteliĵ ine nasē karar verileceĵ i sorunu ortaya

\footnotetext{
${ }^{33}$ I., Inst., 2. 5. 1. Ayrēèa bkz. D. 7. 8. 21. Bir aile evladēya da köle lehine tanēimēé olan kullanma hakkēedan aile reisinin yararlanmasē hakkē devri anlamēna gelmez. Aynēkekilde bir kimsenin, kullanma hakkēkonusu malēeki ve çocuklarēhesabēna kullanējor olmasēda, kullanma

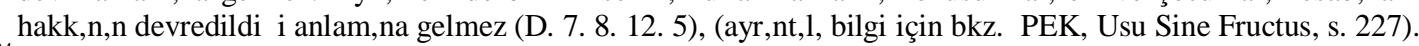

${ }^{34}$ ORTOLAN, s. 351.

${ }^{35}$ Bir evin ya da binanēè buĵ day ambarē ya da karap mahzeni olarak kullanēmasē da habitatio dê̂il, usus kapsamēenda görülmelidir. Zira

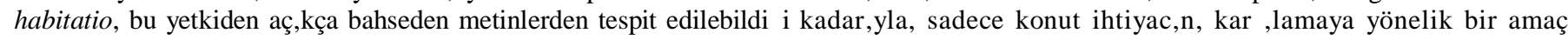
takēe (Bu manada örnek olarak bkz. D. 7. 8. 2. 1; D. 7. 8. 4. 1; ayrēea bkz. ORTOLAN, s. 350-351).

${ }^{36}$ I., Inst., 2. 5. 5.

${ }^{37}$ D. 7. 8. 10 pr., ayrēea bkz. PETIT, s. 253; LEPOINTE, s. 762; ACCARIAS, s. 720; DI MARZO, s. 303.

${ }^{38}$ Fikrimize göre bu sonuç, sadece, habitatioônun maddi bir fiil olarak görüldüj ü klasik hukuk döneme ait dêj ildir, habitatioônun baj ēnsēe bir hak olarak görüldüj ü Iustinianus döneminde de devam etmik olmalēlēe. Zira oturma fiili, bir malēı kullanēmasēndan farklēolarak, aktif bir

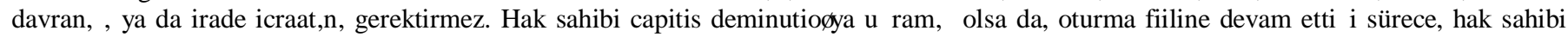
olmaya da devam eder. Mesela ayēt etme gücünü kaybeden bir akē hastasēê̄e evde oturmaya devam etmesi hakkēe devamēiçin yeterlidir, ayrēea irade açẻłlamasēna ya da iradeyi göstermeye yarayan kanaat verici bir davranēka ihtiyaç yoktur. Kaldēki oturma hakkēê̄n ratio legisônin

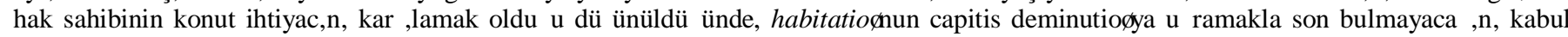
etmek daha makul olur.

${ }^{39}$ D. 7. 1. 1; I. Inst., 2. 4 pr.

${ }^{40}$ D. 7. 8.2 pr.; D. 7.8 .8 pr

${ }^{41}$ I., Inst., 2. 5. 5.

Roma Hukukunda Oturma Hakkē(Habēatēe) 


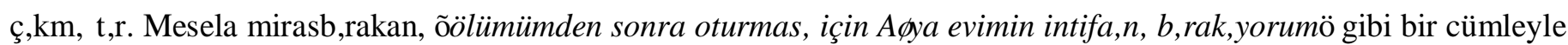
bir vasiyet düzenlemikse, vasiyetnamenin nasē yorumlanmasē gerektî̂ ini belirlemek gerekecektir. Yoruma ilikkin kural ise, D. 7. 8. 10. 2ôle yer almaktadēe:

D. 7. 8. 10. 2 Ulpianus Lib. 17. ad Sabinum

Sed si sic relictus sit illi domus ususfrutus habitandi causa, utrum habitationem solam, an vero et usumfructum habeat videndum? Et Priscus et Neratius putant, solam habitationem legatam: quod est verum. Plane si dixisset testator, usum habitandi causa, non dubitaremus quin valeret.

D. 7. 8. 10. 2 Ulpianus Sabinus hakkē̄daki 17. kitabēidan

Fakat Ku Kekilde vasiyet edildiyse: ñFilanca evin intifa hakkēēenturmasēiçin vasiyet ediyorumò, vasiyet alacaklēēintifa hakkēia mēoturma hakkēe mēsahip olacak? Priscus ve Neratius dükinürler ki burada bir oturma hakkēvasiyeti vardēe, gerçek olan budur. Vasieyet edenin Ku kekilde söyledî̉ inde ise, ñoturma sebebiyle kullanma hakkēēēvasiyet ediyorumò hiçbir tereddüt yoktur.ò

$\mathrm{Bu}$ metne göre, mirasbēeakanē̄ iradesi sadece oturmak için bir kullanma hakkē tanēnak yönünde yorumlanabiliyorsa, oturma hakkēe ürünlerinden yararlandēmak gibi bir amaç da bulundụ̂ u yolunda yorumlanabiliyorsa, intifa hakkēolarak hükme bâj lanacaktēe.

\section{OTURMA HAKKININ KURULMASI}

Klasik Hukuk Döneminde oturma hakkēusus kapsamēnda ele alēnan bir yetkiden ibaret oldû u için, hakkēn

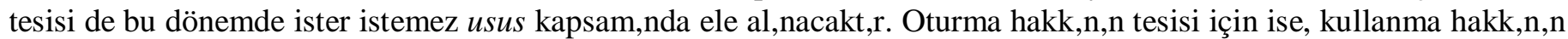

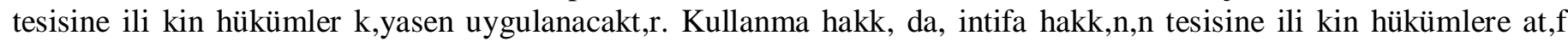

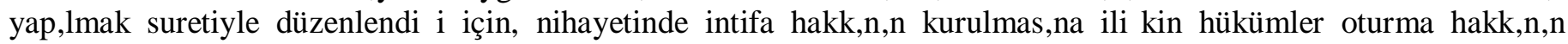
kurulmasēbakēnēindan da geçerli olacaktēe

D. 7. 8. 1. 1 Gaius Lib. 7 ad Sabinum Edictum Provinciale

Constituitur etiam nudus usus, i dest, sine fructu: qui et ipse iisdem modis constitui solet, quibus et ususfructus.

D. 7. 8. 1. 1 Gaius kehir Edictumâl Hakkēidaki 7. Kitabēên

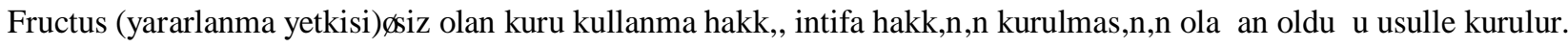
Aynēdüzenleme I, Inst., 2. 5 pr.âla yer almaktadēe:

Isdem istis modis, quibus ususfructus constuitur, etiam nudus usus constitui solet, isdemque illis modis finitur, quibus et ususfructus desinit.

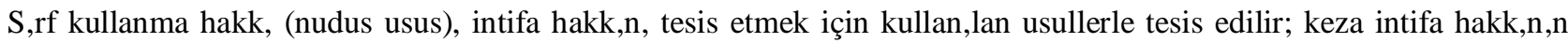
sona erdî̄ i kekillerde nihayet bulur.

Buna göre intifa hakkēhangi usulle kuruluyorsa kullanma ve dolayēēella oturma hakkēda aynēusullerle tesis edilecektir. Kntifa hakkēsậ lar arasēiklem veya ölüme baĵ lētasarruf yoluyla kurulabildî̉ ine göre oturma hakkēda bu yollarla kurulacaktēe. Sẩ lar arasē iklemler yoluyla intifa hakkēề̄ tesisi daha çok in iure cessio yoluyla gerçeklekmikir. Roma hukukunda maddi nitelikte olan mallarē devrinde genellikle mancipatioôa bakvurulmasē

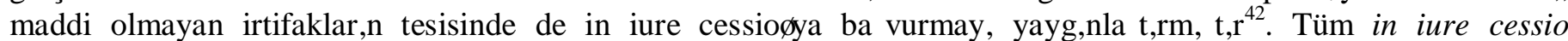

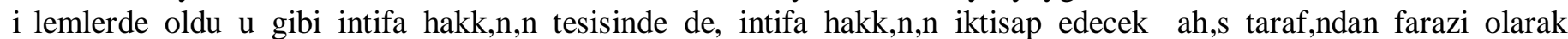
açॄ̄acak bir vindicatio usufructu davasēèda, üzerinde intifa kurulacak malēı maliki bu davayēkabul eder ya da susar ise, intifa hakkēpraetor kararēile tesis edilmikolurdu ${ }^{43}$.

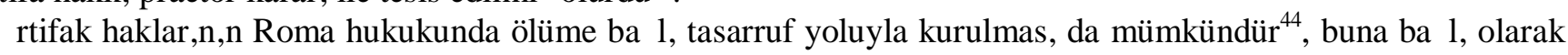
oturma hakkēda vasiyetname yoluyla tesis edilebilir. Düzenledî̂ i vasiyetnamede mirasbēekan, belirli bir kiki lehine bir evde oturma yetkisi tanēnak iradesinde ise, ölüme baĵ lētasarruf yoluyla bir oturma hakkētesis etmik demektir. Bu belirli mal vasiyetinin bir per vindicationem mi yoksa per damnationem mahiyetinde mi oldu $\mathrm{u}$ konusunda ise hakim fikir, per damnationem mahiyetinde oldụ̂ u yolundade $\bar{e}^{45}$.

\section{OTURMA HAKKININ HÜKÜMLERK}

Oturma hakkē hak sahibine bir evde ya da binada oturma yetkisi veren bir hak oldûj una göre, hakkề kullanēnē mutlaka o evin ya da binanēi konut olarak kullanëmasēkeklinde gerçeklekmelidir; bakka amaçlarla kullanēn oturma hakkēkapsamē̄a girmez. Bir ev ya da binada oturmak, aynēzamanda orayēkullanmak demek olacaĵ ềa göre Klasik

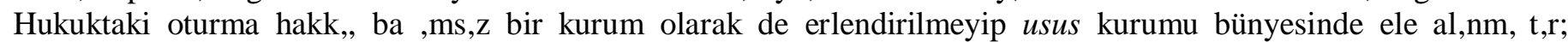

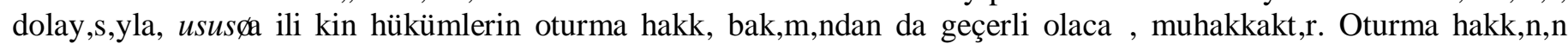

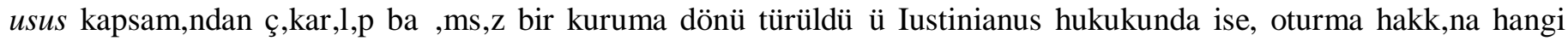
hükümlerin uygulanacaĵ ệa hiç dêি inilmemikir. Gerçekten de ususâan bậ ênsēe bir irtifak hakkēolarak bahseden I.

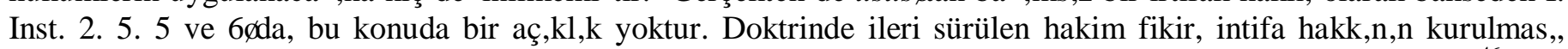
korunmasēve sona ermesine ilikkin hükümlerin oturma hakkēbakēê̄èdan da aynen geçerli olduj u yolundade $\bar{e}^{46}$. Biz

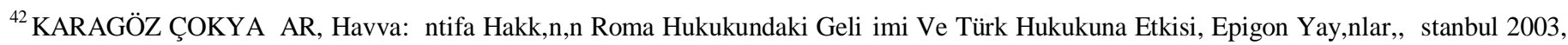
s. 31-33.

${ }^{43}$ Kn̆tifa hakkēēēn tesisinde dî̄ er usuller için bkz. KARAGÖZ ÇOKYAḳAR, s. 75 vd.

${ }^{44}$ HONIG, Richard: Roma Hukuku Dersleri, çeviren: k̦emseddin Talip, Ķıtanbul, 1935, s. 207.

${ }^{45}$ KARADENĶ ÇELEBĶCAN, EKya, s. 263; aynēyönde KARAGÖZ ÇOKYAḳAR, s. 69.

${ }^{46}$ KARADENKZ ÇELEBKCAN, EKya, s. 282; UMUR, EKya, s. 152.

Sevgi KAYAK 
de bu fikre katēēeruz. Esasēđla oturma hakkēile ilgili uyukmazlēklarē, usus dururken niçin ususfructus hükümlerine tabi tutulduj unu ilk etapta anlamak zordur. Çünkü Iustinianus, oturma hakkēēē bầ ênsēe bir irtifak olarak tespit

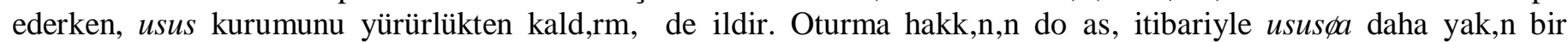
kurum oldụ̂ u düKinüldüĵ ünde, kēasen uygulama bakēnēendan usus yerine niçin ususfructus hükümlerinin tercih edildî̂ i merak konusudur. Gerçekten de hak konusu malẹ̄ ürünlerinden bir yararlanma hakkēsậ lamadê ēiçin her iki

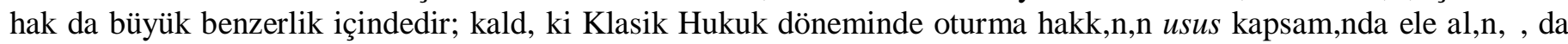

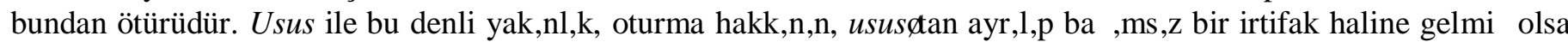

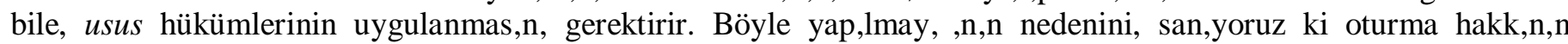

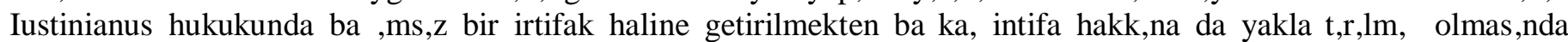

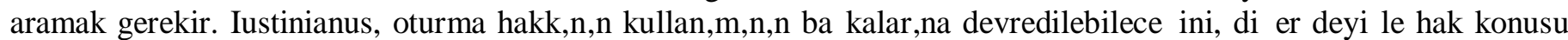
evin bakkalarēe kiralanabileceĵ ini kabul etmekle, hak sahibinin kira gelirinden yararlanmasēea da olanak saĵ lamēđēe,

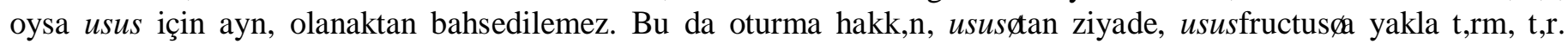
Iustinianus hukukunda oturma hakkē ile ilgili uyukmazlēklarda intifa hakkēe ilikkin hükümlerin uygulanmēe olabilecê̂ i yolundaki hakim görüke, bu gerekçeyle, biz de katēē oruz.

Oturma hakkē̄a kējasen uygulanan usus hükümleri arasēida ilk olarak, hak sahibinin ürün elde etme yetkisinden ï Klasik Hukuk Dönemi için- kural olarak yoksun olmasēgelir. Bununla birlikte kullanma hakkēsahibine, sēê̄lēda olsa, belli kartlar altēida verilen bir ürün toplama hakkēhukukçularēe genikletici yorumlarēsayesindedir. Eĵ er hakkēê kullanēnē ürünlerin toplanmasēèēgerektiriyorsa, bakka deyikle, ürün toplama keklinde bir kullanēndan bakka bir kullanēn mümkün dê̂ ilse, hak sahibine, kendi günlük ihtiyaçlarēēēkarkǣayacak kadar bir ürün toplama yetkisi verilmikir ${ }^{47}$. Örnề in bir sürünün kullanma hakkēēêlde eden kimse, günlük süt ihtiyacēeēpekâlâ bu sürüden karkæ̈ayabilir ${ }^{48}$.

Hemen belirtelim ki kullanma hakkēsahibinin, malēı ürünlerinden kikisel ihtiyaçlarēölçüsünde yararlanmasē konusunda fikir birliĵi içinde olan Romalē hukukçular, bu kikisel ihtiyaçlarēe ölçüsü söz konusu olduĵunda anlaKmazlệ a düKmüklerdir. Nitekim hukukçular arasēeda Sabianus, Cassius, Labeo ve Proculianus; kullanma hakkē

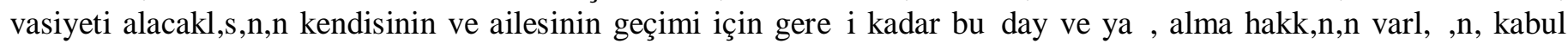
etmiklerdir. Nerva ise; sebze, meyve, su, çiçekler, ahKap ve saman üzerinde de kullanma hakkēvasiyet alacaklēềiè tam hak sahibi olduj unu savunmaktad $\bar{e}^{49}$. Paulus; hak sahibine, kullanma hakkēkonusu maldan ancak bir yēlæk kikisel ihtiyaçlarēê̄e toplamēkadar bir miktarēelde etmesine izin vermektedir ${ }^{50}$. Ulpianusố göre ise, kikisel ihtiyaç ölçüsünün tespitinde önceden bir ölçü verilemez, bu ölçü somut olaya göre deĵ ikkendir ve kikisel ihtiyaçlarēi tespitinde özellikle,

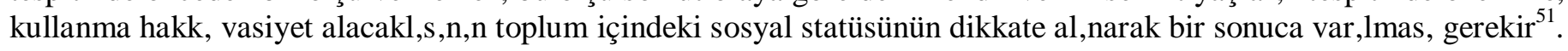
Celsus ise, hak sahibinin sadece kendisi ve ailesi için dê̂ il, davetlileri ve misafirleri için de ihtiyaçlarēölçüsünde bir miktarēelde etmesine izin vererek kullanma hakkēkapsamē̄iaki ürün toplama hakkēêēgenikletmektedir ${ }^{52}$.

Usus bakēnēidan söz konusu olan sēê̄è̄ kekilde ürünlerden yararlanma hakkē ikin doja asēitibariyle oturma hakkēsahiplerine tanēmmayacaktēe. Konut olarak kullanëmaya elveriki bir evin doĵal ürünlerinden bahsedilemez, dolayēēella da oturma hakkēsahibine doĵal ürünlerden yararlanma içerikli bir oturma hakkēzaten tanēnamaz. Ancak

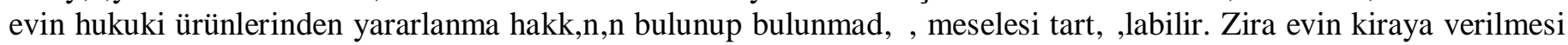

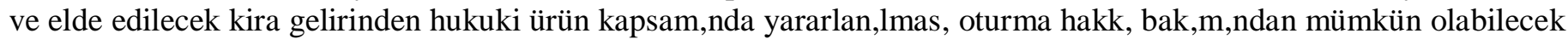
bir kullanēn Keklidir. Klasik Dönemde, oturmak üzere bir kimseye tahsis edilmiK olan evin bakkasēna kiralanmasē hakkēe devri anlamēe gelecề i için kabul edilmemikirr; ${ }^{53}$ ancak Iustinianus hukukunda, Iustinianusồn bir tasarrufu ile bu mümkün kēēèm $\bar{e} t \bar{e}$. Buna göre Iustinianus hukukunda oturma hakkē sahipleri, hak konusu takēmmazē kiraya vererek kira gelirinden de oturma hakkēkapsamēîda yararlanabilirler.

Oturma hakkēêda, hak sahibine sâj lanan as $\bar{\oplus}$ yetki, kural olarak ürünlerden yararlanmaksēēè sâ̂ lanan salt oturma yetkisi olduju için malik, hak sahibinin oturmasệa katlanmak ve bu yetkinin kullanēmasēēēengelleyecek

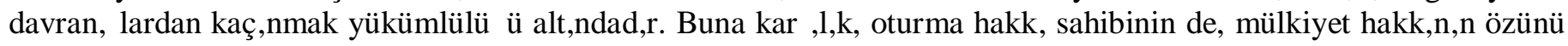
zedeleyecek davranēđlarda bulunmama yükümlülüj ü vardēe. Nitekim D. 7. 8. 23 pr.ôla, kullanma hakkēsahibinin,

\footnotetext{
${ }^{47}$ PETIT, s. 253; CUQ, S. 341; SCHMIDLIN/CANNATA, s. 230; ※EK, Usu Sine Fructus, s. 237.

${ }^{48} \mathrm{Bu}$ husus özellikle D. 7. 8. 12. 2ôde dile getirilmiktir: ñSed si pecoris ei usus relictus est, puta, gregis ovilis, ad stercorandum usurum duntaxat, Labeo ait: sed neque lana, neque agnis, neque lacte usurum: haec enim magis in fructu esse. Hoc amplius, etiam modico lacte usurum puto: neque enim tam stricte interpretandae suntvoluntates defunctorumò. Metinde Labeo, bir koyun sürüsünün kullanēm hakkēēen belirli mal vasiyetiyle bēekēdề ē durumlarda hak sahibinin, bu koyun sürüsünden sadece topraklarēiē gübrelemek için yararlanabilecê̂ ini, zira bu koyunlarē sütünden ve yavrularēendan yararlanma hakkēề̄ intifa hakkēsahibine ait olduĵ undan bahsetmektedir. Bununla birlikte hukukçu,

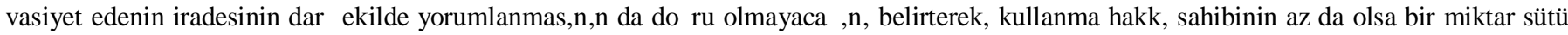
elde edebilecể ini kabul etmektedir. Zira makul olan, bir kimseye bir koyun sürüsünün kullanēnē̄ēvasiyet eden mirasbēekanē̄, hak sahibini bu sürünün ürünlerinden az da olsa yararlandēemak istedî̄ ini düKinmektir.

${ }^{49}$ D. 7. 8. 12.1 .

${ }^{50}$ D. 7. 8. 15 pr.

${ }^{51}$ D. 7. 8. 12. 1; ayrēa bkz. CUQ, s. 341 dn. 4.

${ }^{52}$ Cuq⿳⺈ göre, Celsusồn yaptề èbu yorum kullanma hakkēsahibine ürünlerin neredeyse tamamēēètoplayarak götürme hakkēēēbahketmektedir (CUQ, s. 341 ve s. 341 dn.4).

${ }^{53}$ D. 7. 8.8 pr.

Roma Hukukunda Oturma Hakkēe(Habēatēe) 


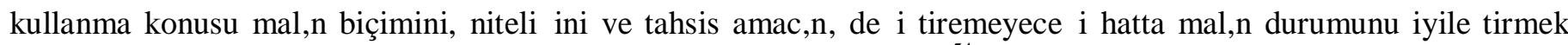
için bile olsa, malikin durumunu kötülekiremeyecề i vurgulanmaktad $\overline{\mathbf{e}}^{54}$.

Oturma hakkēsahibinin sorumluluĵ u bakēēēdan kabul edilen özen ölçüsü, bonus paterfamilias, yani iyi bir aile reisinin göstermesi gereken dikkat ve özendir. Oturma hakkēsahibinin iyi bir aile reisi gibi davranmasēgerektî̉ $\mathrm{i}$ D. 7. 8. 15. 1âle örtülü bir biçimde ifade edilmikir. Hak sahibi, oturma hakkēiēkullanệken iyi bir aile reisinin gösterecê̂ i dikkat ve özen ölçüsünde hareket etmek zorundadēe. Bunu bize özellikle metnin son cümlesi olan ñé aynē Kekilde malikin mirasçēè hakkēēēiyi bir aile reisi gibi kullanan kullanma hakkē sahibine engel olamazò ifadesi söylemektedir ${ }^{55}$.

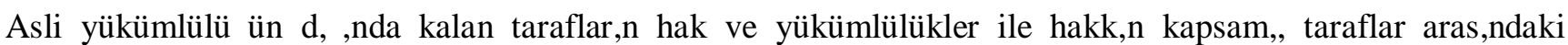
anlakmaya göre tayin edilir. Eĵ er taraflar arasēêda böyle bir anlakma bulunmuyorsa ya da hak sahibinin kullanēm

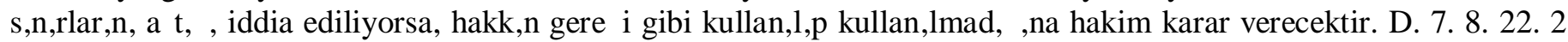
bu hususa ilikkindir:

D. 7. 8. 22. 2 Pomponius lib. 5. Ad Quintum Mucium

Usu legato, si plus usus sit lagatarius quam oportet, officio iudicis qui iudicat, que madmodum utatur, quid continetur?

Ne aliter quam debet, utatur.

D. 7. 8. 22. 2 Pomponius Quintus Mucius hakkēidaki 5. kitabēidan

Eĵ er vasiyet alacaklēēgerekenden daha fazlasēèēkullanēgorsa, gerekli olandan fazlasēèēkullanmamasēiçin kullanma vasiyetinin neyi içerdî̂ ine karar vermek, yargēayan hakimin görevidir.

Bu hüküm oturma hakkēbakēnē dan da kēesasen uygulanacak ve buna göre oturma hakkēsahibi kendisine konut olarak tahsis edilmikbir binayē mesela ticarethane olarak kullanamayacak ya da depo haline getiremeyecektir.

Kullanma hakkē sahibi kullanēn neticesi malikin haklarēề̄ zarar görmeyecể ine dair malike bir güvence verilmek zorunda kalabilir ${ }^{56}$. Güvence verme yükümlülüj ünün oturma hakkēbakēnēendan ifadesi ise, D. 7. 9. 11ôale belirtilmikir:

D. 7. 9. 11 Papianus Lib. 7 Responsarum

Usu quoque domus relicto, viri boni arbitratu cautionem interponi oportet: nec mutat, si pater herdes filios simul habitare cum uxore legataria voluerit.

D. 7. 9.11 Papinianus Cevaplarēè̄ 7. Kitabēidan

Bir evin kullanēnēvasiyet edildị̂ inde, iyi bir aile reisi gibi davranacaĵ ēia dair güvence gösterilmek zorundadē ve hatta bu, babanē evini saj kalan ekine, mirasçēēolan küçük çocuklarēlla birlikte oturmasēēèisteyerek vasiyet etmik olmasē halinde de böyledir.

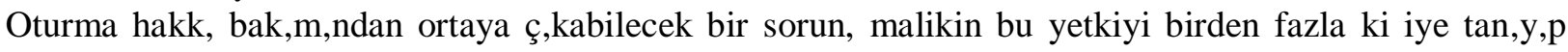

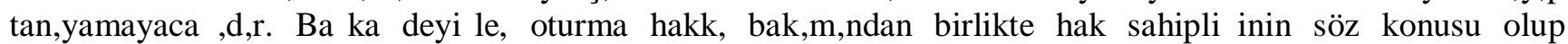
olmadệ ề $\bar{e}$ ki buna cevap D. 7. 8. 22. 1âle buna olumsuz olarak verilmektedir:

D. 7. 8. 22. 1 Pomponius lib. 5. Ad Quintum Mucium

Licet tam angustus est legatarius cui domus usus legatus est, ut non possit occupare torius domus usum, tamen eis quae vacabunt, proprietarius non utetur: quia licebit usuario aliis et aliis temporibus tota domo uti: cum interdum domini quoque aedium, prout temporis conditio exigit, quibusdam utantur, quibusdan non utantur.

D. 7. 8. 22. 1 Pomponius Quintus Mucius hakkēèdaki 5. kitabēendan

Evin tamamēè kullanamayacak kadar kēe olanaklar içinde birine kullanēn hakkēbēakēmasè̄a raĵmen, malik boK yerleri kullanamaz, çünkü dî̄ er yerler bakka zamanlarda kullanđ̄arak evin tamamēdeĵ erlendirilebilir, hal ve kartlara göre kullanma hakkēsahibinin evi kēmen kullan̄̄ kullanmamasēmümkündür.

Aynēçözüm kullanma hakkēbakēê̄idan D. 7. 8. 19âla ifade edilmektedir:

D. 7. 8. 19 Pomponius lib. 5. Ad Quintum Mucium

Usus pars legari non potest: nam frui quidem pro parte possumus, uti pro parte non possumusò.

D. 7. 8. 19 Pomponius Quintus Mucius hakkēêdaki 5. kitabēidan

Kullanma hakkēkēmen vasiyet edilemez, çünkü ürünlerden yararlanma kēmen mümkündür, kullanma hakkēelan kēmen yararlanēamaz.

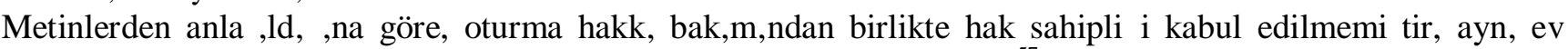
üzerinde aynē anda birden fazla kiki lehine oturma hakkē tesis edilemez ${ }^{57}$. Oturma hakkē belli bir süre için

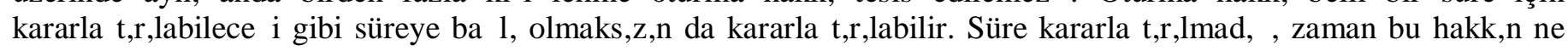

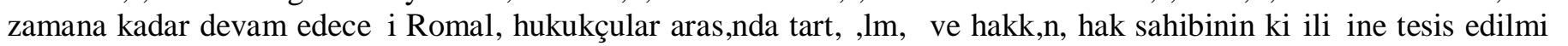
olmasēsebebiyle onun hayatēboyunca devam edecể i kabul edilmikir. Bu sonuç, oturma hakkēề, bir kimsenin konut

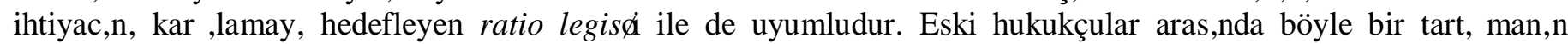

\footnotetext{
${ }^{54}$ Ayrēea bkz. ফৃEK, Usu Sine Fructus, s. 237.

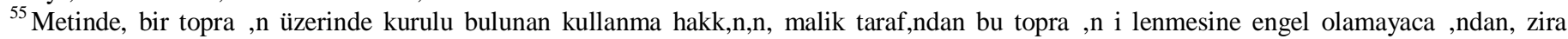

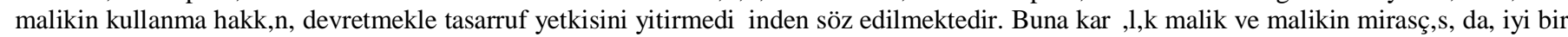
aile reisi gibi davranmakta olan kullanma hakkēsahibini hakkēkullanmaktan men edemeyecektir.

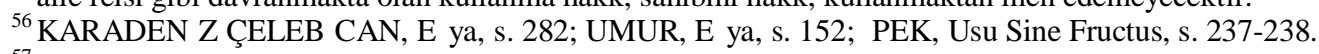

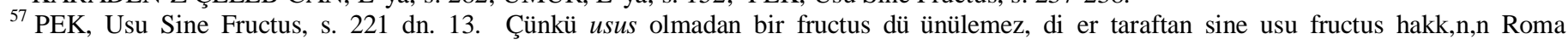

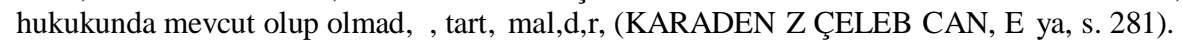




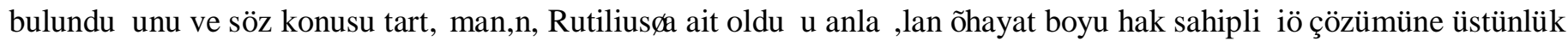
tanēarak sona erdirildî̉ ini D. 7. 8. 10.3 metninden anlēeruz:

\section{7. 8. 10. 3 Ulpianus lib. 17. Ad Sabinum}

Utrum autem unius anni sit habitatio, an usque ad vitam, apud veteres quaesitum est? Et Rutilius döneç vivat, habitationem competere ait: quam sententiam et Celsus probat libro octavodecimo Digestorum.

D. 7. 8. 10. 3 Ulpianus Sabinus hakkē $d a k i$ 7. kitabēidan

Eskiler oturma hakkēēè tüm hayat boyu mu yoksa belli bir sür için mi anlakēmasēgerektî̉ ini irdelediler. Rutilius, oturma hakkēê̄ê, vasiyet alacaklēè ềa, onun tüm hayatē boyunca ait oldụ̂ u fikrindedir ve bu karar Digestaồēi on sekizinci kitabēnda Celsus tarafēndan da onaylanmēètē.

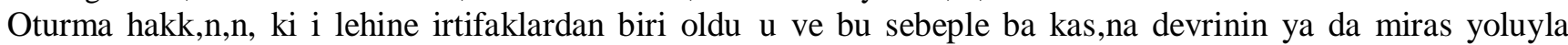

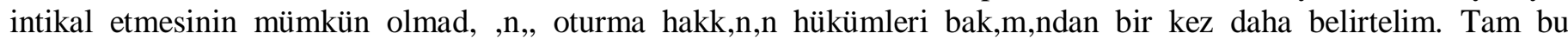
noktada ortaya çđ̄an bir sorun, oturma hakkē sahibinin bu hakkē devretmeksizin hakkēè konusu evi kendi aile fertleriyle birlikte kullan̄̄ kullanamayacaĵ $\bar{e} \bar{e}$. Bu soruna dề inen birkaç metinde buna olumlu cevap verildî̉ $\mathrm{i}$ gözlenir. Örnề in, D. 7. 8. 2. 1âle ve D. 7. 8. 4. 1âte, eklerden birine bēekę̧an oturma vasiyetlerine erkek eK ve kadēn eK bakēnēèdan ayrēayrē dej erlendirme yapëmaktadēe. Kendisine oturma hakkē vasiyet edilen bir erkek ekin sahip oldûे u hakkēēè kapsamēD. 7. 8. 2. 1 âle kaleme alēmmaktadēe:

D. 7. 8. 2. 1 Ulpianus lib. 17. Ad Sabinum

Domus usus relictum est aut marito, aut mulieri: si marito, potest illic habitare non soluk verum cum familia quoque sua. An et cum libertis, fuit quaestionis? Et Celsus scripsit, et cum libertis; posse hospitem quoque recipere: nam ita libro octavodecimo Digestorum scripsit: quam sententiam et Tubero probat. Sed an etiam inquilinum recipere possit, apud Labeonem memini tractatum libro posteriorum? Et ait Labeo, eum qui ipse habitat, inquilinum posse recipere; item et hospites, et libertos suos.

D. 7. 8. 2. 1 Ulpianus Sabinus hakkēidaki 17. kitabēidan.

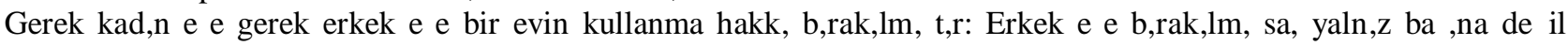
kesinlikle ailesiyle birlikte oturabilir. Bununla birlikte azatlēarēèla oturabilir mi? Celsus yazdē ki azatlēarēẹla da oturabilir, birkaç dostun da kabul edebilir. Çünkü Digestaônēı onsekizinci kitabēnda böyle yazēēèdēve Tiberius kararē oanyladē Fakat sonraki kitaplarēida kiracēkabul edip edemeyecể ini ele alan Labeoôgu hatē̄lēgrum ve Labeo düKinür ki, onun kendisi oturabildî̀ ine göre kiracējēda kabul edebilir: aynēkekilde dostlarēıēve azatlēarēıēda.

Metne göre erkek eK oturma hakkē kapsamēndaki evde yalnē ba kēe deĵil kendi aile fertleriyle birlikte oturacaktēe. Roma aile kavramēiçine, aile reisine kan baĵē evlenme, evlat edinme veya dî̉ er herhangi bir iklemle bậ lēolan herkes dahil oldụ̂ u için tüm bu kikiler oturma hakkēềi saĵ ladê ēyetkilerden yararlanabilirler. Erkek eK

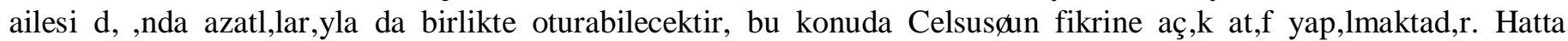
Celsus, azatlēar dēēềda, erkek ekin birkaç dostunu da davet edebilecểi yani misafirlerini de oturma hakkē

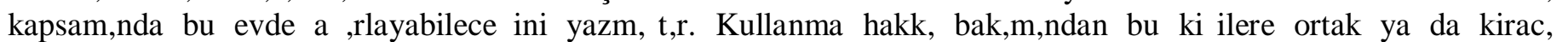
denemeyecể ini de, yine bu metnin yorumu sonucunda anlējoruz. Fikrimize göre erkek ekin ailesinin birlikte hak

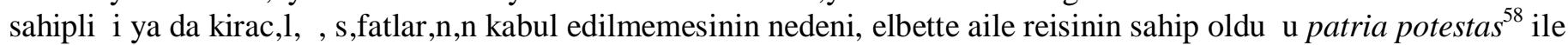
açđęlanabilir ${ }^{59}$.

D. 7. 8. 4. 1 âle ise, kadē eKlehine tanēian oturma vasiyeti kapsamēidan bahsedilmektedir:

D. 7. 8. 4. 1 Ulpianus lib. 17. Ad Sabinum

Mulieri autem si usus relictus sit, posse eam et cum marito habitare, Quintus Mucius primus admisit, ne ei matrimonio carendum foret, cum uti vult domo. Nam per contrarium, quin uxor cum marito possit habitare, nec fuit dubitatum. Quid ergo, si viduae legatus sit? An nuptus contractis post constitutum usum, mulier habitare cum morito possit? Et est verum (ut et Pomponius libro quinto, et Papinianus libro nonodecimo. Quaestionum probat) posse eam cum viro et postea nubentem habitare. Hoc amplius Pomponius ait, et cum socero habitaturam.

\footnotetext{
${ }^{58}$ Patria potestas dilimizdeki karkëề ēla baba hakimiyeti, tüm aile fertleri üzerinde aile reisinin sahip olduj u yetkilerin tamamēdemektir (DI MARZO, s. 163; AYKTER, Kudret: Roma Hukuku Dersleri, Aile Hukuku, Ankara, 1960, s. 45).

${ }^{59}$ Belirtmek gerekir ki Roma hukukunda oturma hakkēsahipleri zilyet olarak kabul edilmemikir. Zira Roma hukukunda fiili hakimiyet bugünkü hukukumuzdan farklēolarak, biri possessio dî̄ eri detentio olmak üzere ikiye ayrēēêē Bugünkü anlamda zilyetliĵ e tekabül eden possessioĝa sahip olanlar; malikler, kendini malik zannedenler yani fiili hakimiyeti iyiniyetle elde bulunduranlar ve fiili hakimiyeti kötüniyetle elde bulunduranlardēe. Detentio ise, bir malēn fiili hakimiyetine zilyetlik kartlarēēètakēnaksēê̄n sahip olmaktēe. Bakka deyikle detentor, az önce

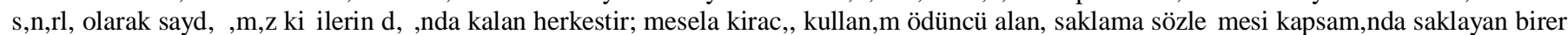
detentorổur. Zilyet ile detentor arasēndaki en büyük fark; zilyetlerin interdictum adē verilen koruma vasēalarēidan yararlandēëmalarēna

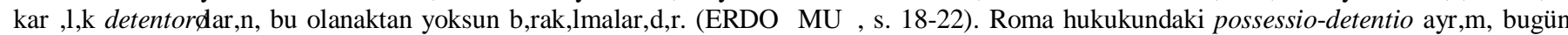

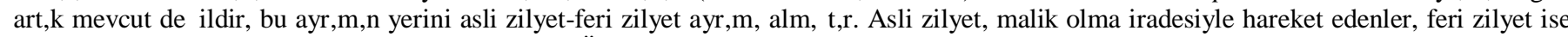
malik olma iradesi olmaksēēè zilyet olanlardēe (GÜRSOY, Kemal T./EREN, Fikret/CANSEL, Erol: Türk Ekya Hukuku, 2. Baskē Ankara Üniversitesi hukuk Fakültesi Yayệ̂larēe Ankara, 1978, s. 73-74; günümüz zilyetlik ve zilyetlik türleri hakkềnda bkz.; ERMAN, Hasan: Ekya

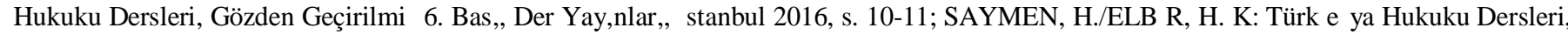
Filiz Kitabevi, Kstanbul, 1963; s. 41; TEKNAY, Selâhattin Sulhi/AKMAN, Sermet/BURCUOĴ LU, Haluk/ALTOP, Atilla: Tekinay Ekya Hukuku, 5. Basē Filiz Kitabevi, K̦tanbul 1989, s. 52-53; DURAL, Mustafa: Ekya Hukuku Dersleri, K̦tanbul, 1981, s. 15). Bu sebeple Roma

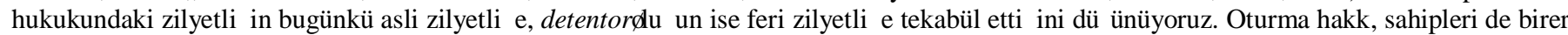
detentorâtur, zira bu kikiler haklarēēēkullanabilmek için malēzorunlu olarak ellerinde bulundururlar, yoksa bunlarēn malik olma iradesiyle malē elde tuttuklarē söylenemez. Nitekim Klasik Hukuk kaynaklarēnda irtifak hakkē sahiplerinden possessor dejil, detentor olarak bahsedilmektedir (KARADENKֵ ÇELEBKCAN, EKya, s. 113). Dî̄ er taraftan oturma hakkē sahipleri, detentor kapsamēenda görülmelerine

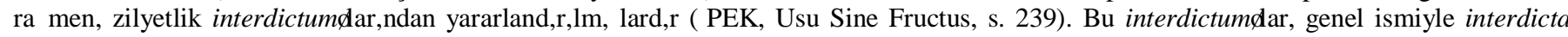

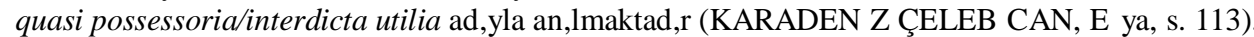

Roma Hukukunda Oturma Hakkē(Habēatēe) 
D. 7. 8. 4. 1 Ulpianus Sabinus hakkēida 17. kitabēidan

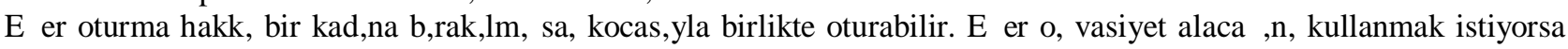
kocasēidan uzak olmamaya mecburdur, buna ilk karar veren Quintus Muciusôur. Zira kocanē kullanma hakkē̄a sahip oldû undan Kiphe edilmez. Eĵ er bir evin kullanma hakkē bir dul kadēia vasiyet edildiyse, bu hakkēkazandēktan sonra yeni bir evlilik akdettî̄i takdirde kocasē ile evde kalabilecek mi? Sorular hakkēidaki on dokuzuncu kitapta Papinianusôın ve 5. kitapta Pomponiusôın; dul kadēe sonradan evlense de, kocasēile aynēevde kalabilecê̂ ini söyleyen kararēēenaylēgrorum, Pomponius bunu kayēipederi ile birlikte oturabilmesine kadar genikletti.

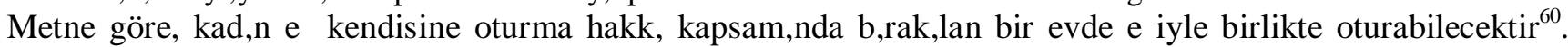
Burada kastedilen, hiç Kuiphesiz, kadē eKe üçüncü kik̉ler tarafēēdan vasiyet edilen bir oturma hakkēlēe. Kadēna, üçüncü kikiler tarafēędan dê̂ il de kendi eki tarafēèdan vasiyet edilen oturma hakkēēēnasē kullanacaĵ ēna ise, metnin ikinci bölümünde cevap verilmektedir. Ölen eKi tarafēidan kendisine oturma hakkētesis edilmik sâj kalan kadēe eK acaba söz konusu evde yeni ekiyle birlikte oturabilecek midir sorusuna olumlu cevap verilmiktir. Buna göre saj kalan kadēi eKin yeniden evlenmesi halinde, ölen kocasētarafēidan kendi lehine tesis edilmik olan evde yeni ekiyle birlikte

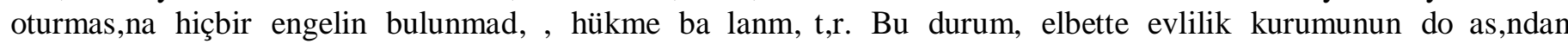
kaynaklan $\overline{\mathbf{e}}$, zira evli eklerin birbirlerinden ayrē yakamalarēbeklenemez. Bir adēn daha öteye giden Pomponius,

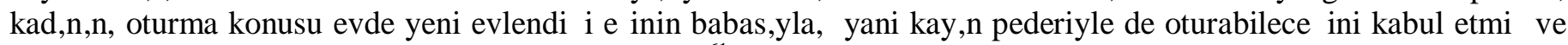
bu suretle hakkē kapsamēēēbiraz daha geniKletmikir ${ }^{61}$.

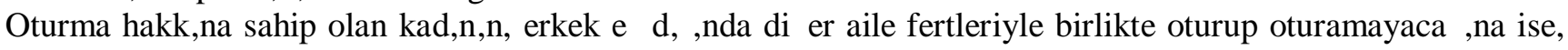
D. 7. 8. 6âla cevap verilmektedir:

\section{7. 8. 6 Ulpianus lib. 17. ad Sabinum}

Non solum autem cum marito, sed et cum liberis libertisque habitare, et cum parentibus poterit. Et ita et Aristo notat apud Sabinum Et hoc usque erit procedendum, ut eosdem, quos masculi, recipere et mulieres possint.ò

D. 7. 8. 6 Ulpianus Sabinus hakkēidaki 17. kitabēidan

Bir evde kullanma hakkēsahibi olan kadē orada yalnēea kocasēgla dej il, çocuklarē ana babasēve azatlēarē la birlikte de oturabilir. Sabinusô göre Aristoônun kaydettî̂ i budur. Bunun, bir erkeĵ in evine kabul edebilecej i aynē̄kahēlarē kadēi için de geçerli olacâ̄ ēkeklinde anlakëmasēgerekir.

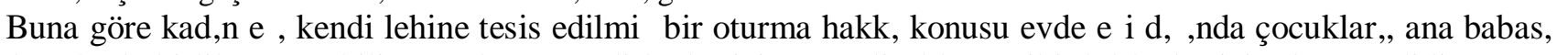

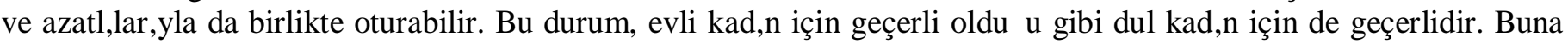

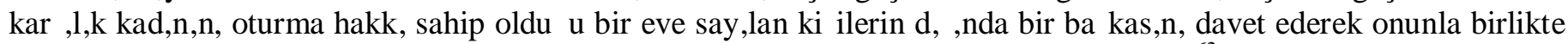
oturmaya kalkmasēbu kikiler bir misafir statüsünde olmadēlarēsürece, kabul edilmemikir ${ }^{62}$.

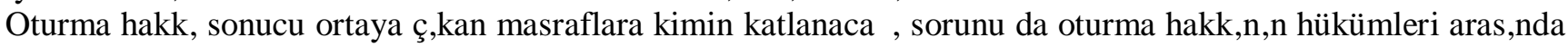
düzenlenmikir. Bu konuda D. 7. 8. 18 pr.ôla özel bir metin sevk edildî̉ ini görüyoruz:

D. 7. 8.18 pr. Paulus lib. 9 ad Plautium

Si domus usus legatus sit sine fructu, communis refectio est rei in sartis tectis, tam heredis quam usuarii. Videamus tamen ne si fructum heres accipiat, ipse reficere debeat: si vero talis sit res, cuius usus relegatus est, ut heres fructum percipere non possit, legatarius reficere cogendus est: quae distinctio ratinem habet.

D. 7. 8. 18 pr. Paulus Plautius hakkēidaki 9. kitabēidan

Ej er birine ürünlerden yararlanma yetkisi olmaksēêè bir evin kullanēnē vasiyet edildiyse, kapalēve çatēē bir evin zorunlu masraflarē mirasçē ve kullanma hakkēsahiplerine birlikte aittir. Bununla birlikte mirasçē evin ürünlerinden yararlanēersa, onarēn masraflarēyalnēeca ona aittir. Êj er kullanma hakkēkonusu mal, mirasçēe ürün saĵ lamayan bir maldan ibaretse, bu onarēnlar vasiyet alacaklēēēna aittir. Bu ayrē̄n bana haklēgörünüyor.

Metinde, kullanma hakkē kapsamēendaki oturma yetkisi bakēnē̄ndan onarēn masraflarēiēi kime ait olmasē gerektîj i tespit edilmektedir. Buna göre onarēnn masraflarē kural olarak, mirasçēile vasiyet alacaklēēena mü Kereken

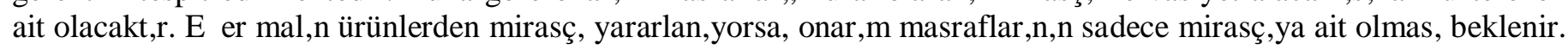
Ej er mal, ürün vermeyen bir mal ise ya da mirasçēbu ürünlerden faydalanamēorsa, onarēen masraflarēēē vasiyet

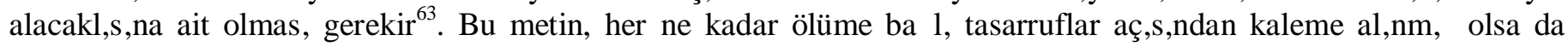
öngörülen çözümün saĵ lararasēiklemler bakēēēidan da geçerli olduĵ unu düKunüyoruz. O halde malik ve oturma hakkē sahibi, hakkēề konusu evin onarēn masraflarēia kural olarak birlikte katlanacaklardēe.

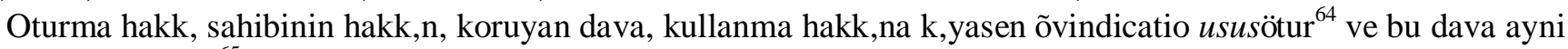
nitelikte bir davad $\bar{e}^{65}$. Oturma hakkē sahibi sadece dava yoluyla dêj il zilyetlik interdictumâarē yoluyla da

\footnotetext{
${ }^{60}$ Zira bu durum fikrimize göre, manusâu evlilik birliklerinde kadēi ekin, erkek eK ya da onun tabi olduj u aile reisinin hakimiyeti altēida olmasēêdan; manusôsuz evlilik birliklerinde ise, birlikte yaKamanēi zorunlu olduĵ u evlilik kurumunun dôj asēendan ileri gelmektedir.

${ }^{61}$ Bunun aksi de mümkündür. Kayēenpeder, kullanma hakkēena sahip oldûj u evde, evin tamamēnda ya da bir bölümünde geliniyle birlikte de oturabilir, zira çộ u zaman bu zorunlu bir sonuçtur. Kayēenpeder, aile ferdi olan ộ luyla birlikte aynēevde oturabileceĵ ine göre ộ lunun eki yani geliniyle de pekala birlikte oturabilir (D. 7. 8. 5).

${ }^{62}$ D. 7.8 .7 .

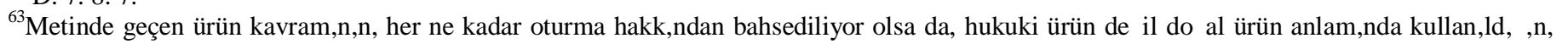
tahmin ediyoruz. Bir evin doĵ al ürünü aslēenda nadiren rastlanabilecek bir olaydēê, mesela bir evin içindeki kuyudan çekilecek su, bu anlamda bir dộ al ürün sayēabilir. Fakat fikrimize göre bir evin bahçesindeki meyve ẩ açlarēburaya girmez, çünkü oturma hakkēyalnēea ev üzerinde olabilir, evin bahçesi oturma hakkēkapsamē̄a dahil edilmik olmayēe bahçe üzerinde kurulacak hak intifa hakkēolarak görülmelidir.

${ }^{64}$ UMUR, EKya, s. 151; ฌeK, Usu Sine Fructus, s. 239.

${ }^{65}$ UMUR, EKya, s. 151.

Sevgi KAYAK 
korunmukur $^{66}$. Yine, oturma konusu mala verilen zararlarda, zararēe tazmini için oturma hakkēsahibinin zarar verene

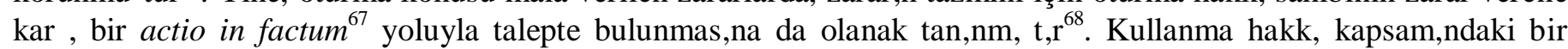

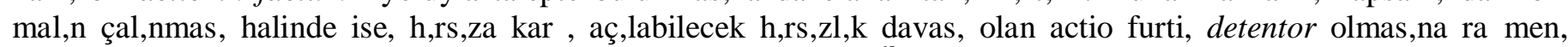

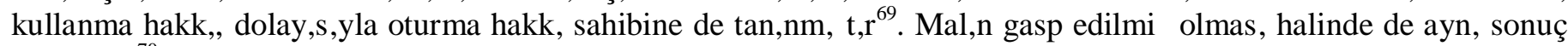
geçerlidir $^{70}$. Ancak hemen belirtelim ki hēēè lē aya da gasp olaylarē ancak bir ev ya da bina üzerinde söz konusu olabilen oturma hakkēbakēnē̄inan elbette gündeme gelmeyecektir.

Iustinianus Hukukuna gelindî̄ inde, irtifak haklarēè ēkoruyan davalar actio confessoria adēaltēinda birlekirilmik ve tüm irtifaklar bu dava ile korunmukur ${ }^{71}$; dolayēè $/ 1$ Iustinianus Hukukunda oturma hakkēè ēkoruyan dava actio confessoria olacaktēe.

\section{OTURMA HAKKININ SONA ERMESK}

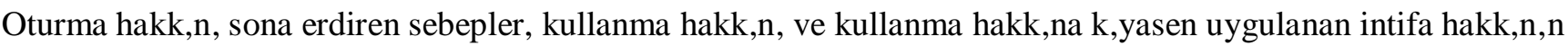
sona erdiren sebeplerle aynēlēe. Buna göre irtifak haklarēēèsona erdiren sebeplerin bakēnda tüm irtifaklar için geçerli dộ al bir sona erme sebebi olan ölüm gelir ${ }^{72}$. Ölümden kasēe, oturma hakkēsahibinin ölümüdür, malikin ölümü hakkē sona erdirmeyip malikin üzerindeki katlanma yükümlülüj ü, terekeyle birlikte mirasçđara geçer. Malēn fiziksel olarak

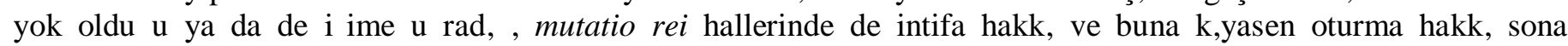
ermektedir. Mutatio reiônin tüm irtifaklar bakēnēèdan, hakkēmēyoksa hakkēı kullanēnēēēmēsona erdiren bir sebep

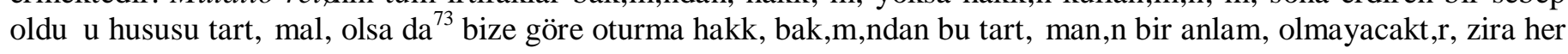
ikisi de aynēsonucu doĵ urur. Bakka deyikle mutatio rei halinde hakkēê kullaneెmasēimkansēèlakmē olacaĵ ềdan, hak

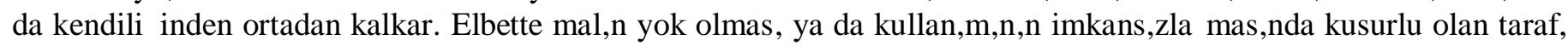
hak sahibine verdî̂ i zararēgidermek zorunda kalacaktēe. Kaynaklarda aç đ̧ça belirtilmemik olmakla birlikte oturma hakkēsahibinin mülkiyet hakkēēēelde etmesiyle de oturma hakkēsona erecektir, çünkü böyle bir durumda malik sēetēē ile oturma hakkēsahibi ș̄atēaynēkikide birlekmiK olacak ve hak kendiliĵ inden sona erecektir. Oturmanē maddi bir fiilden ibaret olmasēsebebiyle, hakkēi kullanēmamasēya da hak sahibinin capitis deminutioôa uj ramasēê̄i oturma hakkēēèsona erdirmeyecêj i de, son olarak ilave edilmesi gereken bir tespittir ${ }^{74}$.

\section{SONUÇ}

Roma hukukunda oturma hakkēe bir ev ya da binanē tamamēida oturma keklinde bir kullanēan ayni nitelikte bir yetkiden ibarettir. Klasik Hukukta oturma hakkēbaj ēnsēe bir irtifak hakkēolarak görülmeyerek, bu hak ñususò adē verilen bir irtifak kapsamēêda ele alēemētēè. Bir evde oturmak, aynēzamanda orayēkullanmak demek olduj undan, bu hak ayrē ve baĵ ênsēe bir hak olarak düKinülmemik usus bünyesinde gerçekleken bir kullanēn keklinden ibaret görülmüкtür. $\mathrm{Bu}$ sebeple Klasik Devirde, ususĉ ilikkin hükümler oturma hakkē bakēnēendan da doĵ rudan uygulanmēètē. Usus kapsamēidaki oturma yetkisi, kikiye bâ lēbir irtifak hakkēolarak görülerek, bakkalarēna devri ya da miras yoluyla intikaline izin verilmemikir. Her ne kadar usus kapsamēêda görülse de, yalnēeca bir ev ya da binada oturmaktan ibaret olmasē ve kullanmama ya da capitis deminutioĝa ụ̂ ramak yoluyla oturma yetkisinin son bulmamasēnedeniyle ususâan; ürün elde etmeksizin bir evi kullanma olanâ̂ ēyaratmasēnedeniyle de ususfructusâan $\operatorname{ayr} \overline{\mathrm{e} m \bar{\Theta}} \overline{\mathrm{e}}$.

Çalēđmamē sonucundaki tespitlerimize göre; günümüzün oturma hakkēile ilgili hükümlerin köklerinin Klasik

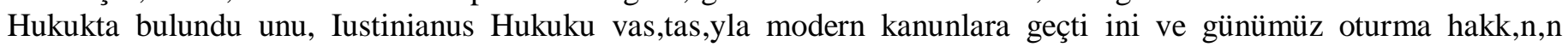
çatēēēēmeydana getirdî̉ ini söylemek yanlēelamayacakt $\bar{e}$.

\footnotetext{
Żarar, Kstanbul, 1999, s. 83 vd.

${ }^{69}$ TAHঝ̦ROj LU, Bülent: Roma Hukukunda Furtum, Kștanbul 1975, s. 144-148.

${ }^{70}$ \EK, Nurcan: Roma Hukukunda Gasp (Rapina), Kstanbul 2001, s. 91 vd. Yetkin Yayēilarē Ankara 2014, s. 89.

${ }^{72}$ एEK, Usu Sine Fructus, s. 243.

${ }^{73}$ Tartēermalar hakkēnda ayrētēeiçin bkz. KARAGÖZ, s. $241 \mathrm{vd.}$

${ }^{74}$ D. 7. 8. 10; ayrēa bkz. ACCARIAS, s. 353; CUQ, s. 342.

Roma Hukukunda Oturma Hakkē(Habēatēe)
}

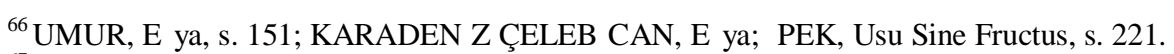

${ }^{67}$ Actiones in factum conceptae; ius civileâle dava hakkēbulunmayan bir hukuki ilikkinin, hakkaniyet gereĵ i himayeye layß̉ görülmesi halinde, hukuken tanēmmasēnēsậ lamak için praetor tarafēndan tanēnan davalara verilen ortak isimdir (UMUR, Lügat, s. 15).

${ }^{68}$ WeK, Usu Sine Fructus, s. 240. Lex Aquiliaốla ise bu davalarē̄ yalnēerca malike ait olduj u hakkēerda bkz. SOMER, Pervin: Mala Verilen

${ }^{71}$ Iustinianus döneminde tüm irtifak haklarēēèkoruyacak tek bir davaya ihtiyaç duyulmuk ve Klasik Hukuktaki irtifak haklarēıēkoruyan dava vindicatio servitutis ile intifa hakkēēēkoruyan vindicatio ususfructus birlektirilerek, tüm irtifak haklarēēèkorumaya elveriki ñactio confessoriaò adēella anēan bir davaya dönüKürülmükür. (ÖCAL APAYDIN, Bahar: Roma Hukukundan Günümüze TaKēemaz Lehine Kর̣tifak Haklarēē 


\section{KAYNAKÇA}

ACCARIAS, C.: Précis De Droit Romain, Tome I, 4. éd., Paris 1891.

AYBAY/HATEMĶ EKya Hukuku, Vedat Kitapçęæe, K̦stanbul 2014.

AYK̦TER, Kudret: Roma Hukuku Dersleri, Aile Hukuku, Ankara, 1960.

CUQ, Edouard: Manuel Des Institutionis Juridiques Des Romains, 2. éd, Paris, 1928.

DI MARZO, Salvatore: Roma Hukuku, 5. Tabô̂̃̂̀dan çeviren: Ziya Umur, K̦stanbul 1959.

DUMONT, François Les Donations Entre Epoux En Droit Romain, Paris, 1928.

DURAL, Mustafa: EKya Hukuku Dersleri, K̦tanbul, 1981.

EMĶৃOĴ LU, Haluk: Roma Hukukunda Kadēê̄i Durumu, Ankara, 2003.

ERDOĴ MUḳ, Belgin: Roma Ekya Hukuku, Der Yayē̄larē K̦stanbul 2000.

ERMAN, Hasan: Ekya Hukuku Dersleri, Gözden Geçirilmik6. Basē Der Yayēilarē Ķ̦tanbul 2016.

ESENER, Turhan / GÜVEN, Kudret: Ekya Hukuku, Genikletilmik6. Baskē Ankara, Yetkin Yayēilarē 2015.

GÜNEk̦ CEYLAN, Seldaĵ, ñRoma Hukukunda Klasik Hukuk Dönemiò, Prof. Dr. Belgin Erdô̂ mukâ Armajan, Derleyen: M. Murat K̦̣ceoĵ lu, Der Yayēilarē K̦stanbul 2011.

GÜRSOY, Kemal T./EREN, Fikret/CANSEL, Erol: Türk Ekya Hukuku, 2. Baskē Ankara Üniversitesi Hukuk Fakültesi Yayēllarē Ankara, 1978.

HONIG, Richard: Roma Hukuku Dersleri, çeviren: ķemseddin Talip, Ķıtanbul, 1935.

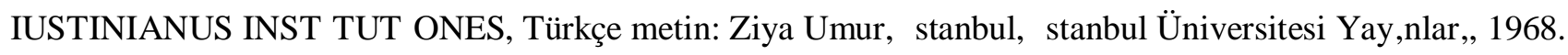

\ִEK, Nurcan: ñRoma Hukukunda Kullanma Hakkē(Usu Sine Fructus)ò, (Usu Sine Fructus), Maltepe Üniversitesi Hukuk Fakültesi Dergisi, 2009/1.

«ৃEK, Nurcan: Roma Hukukunda Gasp (Rapina), K̦tanbul 2001.

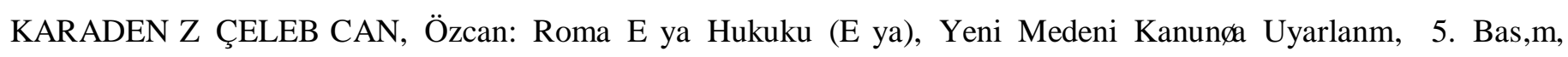
Turhan Kitabevi, Ankara 2015.

KARADENĶ ÇELEBĶCAN, Özcan: Roma Hukuku, (Roma Hukuku), Yeni Medeni Kanunĉ Uyarlanmēe On Yedinci Basē̄n, 2014, Turhan Kitabevi, Ankara 2014.

KARAGÖZ ÇOKYAḳAR, Havva: Ķntifa Hakkēēēn Roma Hukukundaki Gelikimi Ve Türk Hukukuna Etkisi, Epigon Yayēilarē 2003.

KARAGÖZ, Havva: Traditio (Teslim)ônun Tarihsel Gelikimi Ve Constitutum Possessorium (Zilyetlik Anlakmasēe, Der Yayēllarē K̦̦tanbul 2001.

KÖPRÜLÜ, Bülent /KANETĶ Selim: Sēệ̂lēAyni Haklar, Genikletilmikve Yenilenmik2. Basē Ḳtanbul, 1982-1983.

LEPOINTE, M: Cours De Droit Romain, Paris, 1948-1949.

MONIER, Raymond: Manuel Elémentaire De Droit Romain, Tome I, 6. édition, Paris 1947.

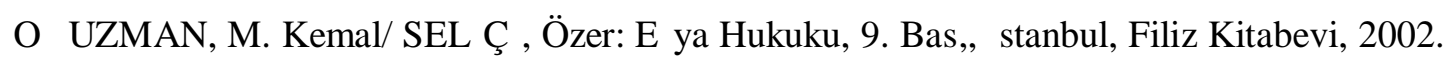

ORTOLAN, M.: Explication Historiques Des Instituts De LâEmpéreur Justinien, Tome II, 8. éd., Paris, 1870

ÖCAL APAYDIN, Bahar: Roma Hukukundan Günümüze Takēmmaz Lehine K̦ttifak Haklarē Yetkin Yayệlarēe Ankara 2014.

PETIT, Eugène: Traité Elémantaire de Droit Romain, 9. éd., Paris 1925.

SAYMEN, H. / ELBł̦, H. K.: Türk Ekya Hukuku Dersleri, K̦tanbul, Filiz Kitabevi, 1963.

SAYMEN, H./ELBß̦, H. K: Türk EKya Hukuku Dersleri, Filiz Kitabevi, K̦tanbul, 1963.

SCHMIDLIN, Bruno/ AUGUSTO CANNATA, Carlo: Droit Privé Romain, II, Lausanne, 1987.

SEIDL, Erwin: Römisches Privatrecht, 1963. 
Sł̦RMEN, Lale: Ekya Hukuku, 4. Baskē Ankara, Yetkin Hukuk Yayēēlarēę 2016.

TAHAN ORHAN, Duygu: Roma Hukukunda Manus Kurumu, On K̦i Levha, Ķıtanbul 2018.

TAHজ̧ROĴ LU, Bülent/ERDOĴ MUk̦, Belgin: Roma Hukuku, Onuncu Basēn, Der Yayēêlarēẹ K̦tanbul 2014.

TAHঝ̣ROJ LU, Bülent: Roma Hukukunda Furtum, K̦̦tanbul 1975.

TEKর̦NAY, Selâhattin Sulhi/AKMAN, Sermet/BURCUOĵ LU, Haluk/ALTOP, Atilla: Tekinay Ekya Hukuku, 5. Basē Filiz Kitabevi, K̦tanbul 1989.

UMUR, Ziya: Roma Hukuku Lügatẹ K̦̦tanbul Üniversitesi Yayēıllarē K̦tanbul, 1983.

UMUR, Ziya: Roma Hukuku, Ekya Hukuku (Ayni Haklar), (Ekya), Filiz Kitabevi, K̦tanbul 1985.

UMUR, Ziya: Roma Hukuku, (Roma Hukuku), Filiz Kitabevi, K̦tanbul 1984. 